\title{
PUBLIC AND SEMI-PUBLIC CORPORATIONS IN FRANCE*
}

\author{
Winfried R. Dallmayr $\dagger$
}

\begin{abstract}
INTRODUCTION
For a long time and not without justification, French administrative law has
\end{abstract} been admired for its clarity and conceptual vigor. The lucid rational formulation of the chose publique and the distinction between the domains of public and private law were treasured acquisitions of the French Revolution and of classical Liberalism. However, even the Revolution did not entirely abolish the intermediary corporate bodies of the Old Regime. More importantly, the end of the nineteenth and the beginning of the present century witnessed a gradual obliteration of the traditional state concept and an expanding interaction between public activities or services and private, socio-economic endeavors.

This development of public services, ${ }^{1}$ and the concomitant transformation of their character, evoked different responses among the leading publicists and administrative lawyers of the time. Commenting on a decision of the Council of State at the turn of the century, Maurice Hauriou argued forcefully that the penetration of public services and institutions into the social and economic sphere endangered the classical Liberal concept of the state, the distinction between the political and the social or collective realms, and in the end, the rule of law itself. ${ }^{2}$ A more positive and

* The following abbreviations are used: C.E. for Conseil d'Etat; T.C. for Tribunal des Conflits; C.C. for Cour de Cassation. In reference to the latter court, Civ. stands for Chambre civile, Crim. for Chambre criminelle, Soc. for Section sociale, Comm. for Section commerciale, Req. for Chambre des requêtes. D. refers to Dalloz périodique; D.A. to Dalloz analytiquse; D.H. to Dalloz hebdomadaire; D. Crit. to Dalloz critique; S. to Sirey; Rec. to Recueil Lebon (i.e., Recueil des arrêts du Conseil d'Etat et du Tribunal des Conflits) of the year in which the decision was rendered; J. stands for Jurisprudence; Somm. for sommaire or summary of a decision; Chron. for Chronique; Doctr. for Doctrine; concl. for conclusion (of a commissaire du gouvernement); J.C.P. for Juris-classeur périodique (La semaine juridique); R.D.P. for Revue du droit public et de la science politique; DR. Soc. for Droit social; REv. ADM. for Revue administrative; C.J.E.G. for Cahiers juridiques de l'électricité et du gaz. Court decisions are cited in the French manner. Thus, C.E., March 4, 19I0, Thérond, S.I9II.3.17, concl. Pichat, R.D.P. 1910.353, note Jèze, stands for decision of Council of State of March 4, I910, reported in Sirey, year I91x, part 3, p. 17, with conclusions by Pichat, also reported in Revuse du droit public et de la science politique, year I9I0, p. 353 , with note of Jèze. For the sake of uniformity, references to R.D.P. are always cited in the French manner. Citations starting with the name of a city or district refer to decisions of lower courts. Where no court is indicated, citation refers to the court which rendered preceding decision or decisions. All quotations from French publications have been translated into English by the writer of this article.

+ Dr. iur. I955, University of Munich, Germany, Ph.D. I96o, Duke University. Department of Political Science, Milwaukee-Downer College, Milwaukee, Wis.

${ }^{1}$ On the notion of service public, see subsequently in the text, especially notes $21,22$.

${ }^{2}$ See T.C., Dec. 9, I899, Association syndicale du canal de Gignac, S.I900.3.49, as discussed in I Maurice Hauriod, La Jurisprudence Administrative de $1892 \AA$ 1929 , at 415, 4r6, 422 (r929). In his comments on subsequent decisions, Hauriou was not entirely hostile to mixed corporations (i.e., bodics displaying public and private law ingredients) provided that economic endeavors were not absorbed by the state itself; compare C.E., May 22, 1903, Caisse des écoles du VIe arrondissement de Paris, S.r905.3.33, discussed id. at 433 . 
optimistic attitude was taken by Léon Duguit and his followers. Considering the state simply as a factual power relationship, Duguit aimed at a complete reformation and reorientation of French administrative doctrine, centering on a broad concept of public service and eliminating the traditional notions of public power and authority..$^{3}$

Whatever may have been the merits and effects of this reform movement, the proliferation of public services during subsequent decades reached proportions which could not have been expected or foreseen by Duguit and his school. Public corporations multiplied in all areas of social life and frequently assumed functions of a definitely commercial or industrial nature. At the same time-owing to the piecemeal character of the entire process-the traditional state structure was by no means abandoned or overcome, ${ }^{4}$ with the result that the dichotomy of public and private law continued to serve as a cornerstone of administrative doctrine and jurisprudence. In this situation, the legal regime applicable to the developing services and institutions assumed kaleidoscopic features betraying an ingenious variety of combinations of public and private law ingredients. The following pages attempt to portray the major forms of such combinations, starting from organisms governed almost entirely by public law and proceeding to semi-public institutions and finally to private enterprises only vaguely affected with a public interest.

\section{I}

\section{Public Corporations}

The establishment of public corporate bodies constitutes the most prevalent device for handling matters transcending the sphere of purely private interests. Basically, even the state itself is nothing but a public body designed to realize such basic aims as peace and security. Frequently, the state accomplishes its functions in a direct manner, without delegating them to intermediary public organisms. ${ }^{5}$ In modern governments, the major examples of this direct operation are military defense, police, and the administration of justice. In other instances, the state may entrust public functions to separate entities whose character is primarily determined by their relationship to a part of the national territory, i.e., the various agencies of governmental decentralization such as regions, provinces, "départements," districts, municipalities, or other forms of local government. Both the direct performance of

\footnotetext{
${ }^{3}$ Compare esp. Léon Duguit, Les Transformations du Droit Public chs. 1,2 (19r3). For a strong criticism of Duguit's elimination of puissance publique and for a proposal to coordinate this notion with the concept of public service, see M. Hauriou, Précis DE Droit Administratip et pe Droir Public XII-XV (IIth ed. 1927) [hereinafter cited as Hauruou, PrEcis].

As a corollary, the notion of puissance publique was not entirely discarded by administrative doctrine; compare Marcel Waline, Droit Administratif 93, 357 ( $\$ \$$ 157, 602) (8th ed. 1959) [hercinafter cited as Waline]; I Georges Vedel, Droit AdMinistratif 20 f., 54, 59 (x958) [hereinafter cited as VeDEL, Dr. ADM.].

"In French administrative law, this form of administration is called régie or régie directe; see Waline 624 ( $($ I057); 2 Vedel, Dr. Adm. 568; AndrE de Laubadère, Manued de Droit Administratif 22, 208 (3d ed. I95I) [hereinafter cited as DE LAUBADÈRE].

'On the territorial circumscription département, compare WALINE 325 ff. ( $\$ 5540$ ff.); 2 VEDEL, Dr. AdM. 431 ff.; De Laubadère 157 ff; Haurjou, Prf́cis 146 ff.
} 
public functions by the state and administration through territorial agencies remain outside the scope of the present study.

Apart from the state and its territorial subdivisions, public functions and services are on numerous occasions exercised by public bodies which are characterized not so much by the territory in which they operate but by their specialized functions. In France the major type of these functional entities is traditionally called établissement public. Until the period of the second World War, it was still possible to describe the établissement public as a "residual category" comprising all public corporate bodies which are not territorial in character. ${ }^{7}$ In more recent years, however, a trend has developed both in legal doctrine and in court decisions to distinguish several categories within the larger concept of non-territorial "public corporations." Basing himself on statements of Léon Michoud ${ }^{8}$ and, to some degree, on German legal doctrine, Robert Drago has urged the differentiation of public legal bodies into foundations and associations, that is, into bodies which are based on special funds and equipped with representative organs only by the state, and bodies which are formed by actual associations of persons. ${ }^{9}$ Drago's proposals have not been without influence on other writers in the field of administrative law..$^{10}$ At the same time, French administrative courts have started to admit the existence of public law organisms which are based on professional organizations or associations and which, nevertheless, are not classified as établissements publics. ${ }^{11}$

Unfortunately, however, these doctrinal and judicial efforts have not resulted in a neat and uniform classification. The acceptance by administrative courts of a separate category of association-type public organisms remains limited to a number of professional corporations, while the term établissement public continues to be applied to a large variety of public entities comprising both those characterized by a special fund and those based on associations other than professional organizations. The following presentation therefore follows the actual practice of French courts rather than the requirements of doctrinal neatness.

\section{A. Etablissements Publics}

\section{r. Introduction}

The term établissement public in France dates back at least to the Civil Code of 1804 and the Code of Civil Procedure of $1807 .{ }^{12}$ Despite the suppression of guild

${ }^{7}$ See WaLine 352 ( $\left.\$ 594\right)$.

${ }^{8}$ I L Lon Michoud, La Théorie de la Personnalité Morale et Son Appitcation au Droit Français 209 ff. ( $\$ 75$ ff.) (3d ed. 1932).

'Rozand Drago, Les Crises de la Notion d'établissement Public (1948); Drago, The Public Corporation in France, in W. Friednann (Ed.), The Public Corporation II3 (I954).

${ }^{10}$ See, e.g., P. Duez \& G. Debeyre, Tratté de Droit Administratif I62 0.5 (1952). On the other hand, Waline inclines to the view that the destinaries of the services of an institution constitute its sociological substratum; WarINE 254-55 ( $\$ 4 \mathrm{IO}$ ).

${ }^{11}$ C.E., July 31, 1942, Monpeurt, S.r942.3.37, concl. Ségalat, R.D.P.r943.57, note Bonnard; April 2, 1943, Bouguen, S. 1944.3.1, concl. Lagrange, note Mestre.

12 Civil Code arts. 940, I712, 2045, 2121, 2227; CoDe of Civ. Proc. arts. 69, 83, I032, and former art. 336 (prior to revision by law of May 23, 1942). For the term établissement d'utilité publique, compare CiviL. Code arts. 9ro, 937. 
and local government bodies in I79I, and in contrast to the individualistic or atomistic philosophy of the Revolution, the term appeared at the time as a legacy of the Ancien Regime, comprising various royal foundations such as hospitals and poor houses, and a number of new institutions such as universities and colleges, modeled after pre-revolutionary institutions. ${ }^{13}$ However, while containing some fragmentary rules concerning the financial administration of corporations, the Napoleonic Codes did not define or clearly circumscribe the term établissement public. It was not until 1856 that the courts made an effort to distinguish between corporate bodies of public law (établissements publics) and private institutions acting in the public interest (établissements d'utilité publique). ${ }^{14}$ This effort was significant mainly for establishing an external line of demarcation; it did not entirely clarify the internal nature of public corporations. The proliferation of public corporations since the turn of the century and especially their infiltration into the social and economic domains have greatly complicated the problem of classification and definition. Some writers have gone so far as to claim that the term établissement public has entirely lost its juridical significance and merely serves as a loose catchword for diverse entities and institutions. ${ }^{15}$

While the latter attitude is hardly representative of the majority of doctrinal and judicial opinion, the difficulties involved in the definition of établissements publics cannot be overlooked. The awareness of such difficulties has given rise, already some decades ago, to a "subjective" theory-advocated primarily by Gaston Jèzeaccording to which the will of the legislature alone determines the qualification of an institution as établissement public. ${ }^{16}$ Despite the apparent simplicity of this theory, it should be pointed out that the legislature very rarely designates a corporate body expressly as établissement public. Even where such direct terminology is employed, the wording of the statute may on occasion be misleading. This is particularly true in the case of laws passed prior to 1856 or 1860 , when, in the words of the Council of State, "the meaning of such terms was not yet well defined."17 If the statute establishing the institution does not contain a clear designation, the subjective theory holds that the intention of the legislature has to be scrutinized. ${ }^{18}$ However, the scrutiny obviously impels courts to examine the various powers and functions

\footnotetext{
${ }^{13}$ See Drago, op. cit. supra note 9, at 3I ff. On corporative institutions under the Old Regime, compate F. Olivier-Martin, L'Organisation Corporattve de za France d'Ancien Regme (I938).

${ }^{14}$ C.C., Civ., March 5, x856, Caisse d'Epargne de Caen, S.1856.1.517, D.1856.1.121 (held that local savings banks are établissements d'utilité publique). The distinction was adopted by a law of Feb. 21, I862, concerning loans of public corporations.

${ }^{15}$ See, e.g., Culmann, Existe-t-il un droit professionel autonome?, Revue de I'Économe CoNTEMPoraine 3, at I6 (I944). Vedel comes very close to this view when' he writes: "In fact, the term établissement public does no longer correspond to a uniform legal definition or a uniform juridical regime." 2 VEDEI, DR. ADM. 480.

20 Gaston Jèze, Les Principes Génf́raux du Droit Administratif 28 (3d ed. i930); De LAUBADÈRE $23,212$.

${ }^{17}$ C.E., Dec. 2I, 1906, Caisse diocésaine de secours de Gap, Rec.p.947; also June 20, 1919, Brincat, D.I922.3.15, note Puget, S.r924.3.43, R.D.P.1920.80, note Jèze.

${ }^{18} \mathrm{JEzzE}$, op. cit. supra note 16 , at 30 ; but in order to discern the legislative intent, Jèze admits that recourse must be had to the "basic concept" of the établissement public which, in his view, consists of the possession of a separate fund and the performance of a public service.
} 
attributed to a particular corporate body. Thus, even under the subjective theory, the definition of an établissement public still turns mainly on the powers and functions of each individual institution.

At the turn of the century, Hauriou proposed defining the établissement public as "an administrative body which conducts a special public service."10 This definition, which greatly influenced subsequent doctrinal developments, ${ }^{20}$ implies that the institution so defined constitutes a public legal entity which is separate of and distinguished from the state and which conducts a specialized public service. The latter was definitely the major aspect of the definition. Duguit and his followers were at that time in the process of overhauling French administrative theory, and used the idea of "public service" (service public) as a cornerstone of the new system. ${ }^{21}$ However, in more recent decades, the meaning of the term "public service" has become increasingly vague and fluctuating ${ }^{22}$ and, while it continues to be an important

${ }^{10}$ M. Hauriou, Précis de Droit Administratif 504 (4th ed. Ig0I). In his Précis (cited supta, note 3), Hauriou describes the établissement public as a juridical person performing a specialized public service; see also Précis El Ementaire de Droit Administratif I3I (2d ed. 1930) [hereinafter referred to as Hauriou, Précis Élém.].

${ }^{20} 3$ Dugurt, Traité De Drort Constrtutionnel 343 (3d ed. 1930), describes établissements publics as public services endowed with a special fund; for a similar definition compare Louis RoLland, PREcrs de Droit administratif 34 ( $(42)$ (9th ed. I947). De Laubadère, 210 ff., defines the établissement public as a decentralized public organism performing a special public service. According to 2 VEDEL, $D_{R}$. ADM. 465, the "classical" concept of établissement public requires a juridical person of public law performing a public service.

${ }^{21}$ Compare L. Duguit, Les transformations du Droit Public (Igr3); R. Bonnard, Précis de Droit Administratif (4th ed. I943); and the cited works of Jèze and Rolland. On this "école du service publics" see I VEDEL, DR. ADM. 48-5I. For some famous court decisions of the period utilizing the criterion of "public service," compare T.C., Feb. 8, I873, Blanco, D.1873.3.17, concl. David, S.1873.2.153, concl. David (held that state responsibility for damages caused by agents employed in the public service comes within the jurisdiction of administrative courts); C.E., Feb. 6, 1903, Terrier, D.1904.3.65. concl. Romieu, S.I903.3.25, concl. Romieu, note Hauriou (where administration had promised payment for killing of snakes, act of killing constituted a public service and litigation relative to the service belonged before administrative tribunals); T.C., Feb. 29, 1908, Feutry, S.r908.3.97, concl. Teissier, note Haurioú, R.D.P.rgo8.266, note Jèze (liability of a département for damages caused by mental patient escaped from département asylum is determined by administrative courts); C.E., March 4, 19I0, Thérond, S.I9I1.3.I7, concl. Pichat, note Hauriou, R.D.P.ıg10.353, note Jèze (administrative tribunals have jurisdiction over contract of municipality for performance of a public service, in the instant case the service of a dogcatcher). See also, Chardes E. Freedeman, The Conseil d'État in Modern France im8-122, I4j2143 (196r).

22 This term may designate either an activity or an organism performing this activity, and has been rendered ambiguous by the fact that the administration may exercise a public service in private law form (gestion privee); by the rise of industrial or commercial public services; and by the application of zdministrative law to areas unrelated to a public service; see C.E., June 10, 1929, Commune de Monségur, S.I92r.3.49, note Hauriou. Some writers today go so far as to relegate the term to the realm of empty 3 logans or of "legal existentialism"; of. Chenot, La notion de service public dans la jurisprudence śconomique du Conseil d'Etat, 4 ETudes ET DocuMENTs 77 (1950); Rivero, Existe-t-il un critère du droit sdministratif?, R.D.P.1953.259; I VEDEL, DR. ADM. $5 \mathrm{I} f$. While recognizing the vagueness of the term, Waline proposes an approximate definition to the effect that public service consists of an activity of public interest in which public authorities-without necessarily assuming financial responsibility-have taken the initiative and over which they exercise some form of control; Waline 624 ( $\S$ I057). The term continues to be used by courts: T.C., Nov. 3, I958, Daubie, R.D.P.r959.615; C.E., April 20, 1956, Epoux Bertin, D.1956.J.433, note de Laubadère, R.D.P.I957.I01, note Waline; Oct. 19, 1956, Soc. Le Béton, D.I956.J.68r, concl. Long; T.C., March 28, 1955, Effimieff, J.C.P.I955.2.8786, note Blaevoet. Accepting the modern proliferation of public services, the Tribunal of Conflicts attempted to introduce 2 new category of services publics socials which supposedly are subject to private law, at least in their relation to employees and users; T.C., Jan. 22, I955, Naliato, Rec.p.614, D.1956.J.58, note Eisenmann, 
concept of administrative law, its utility for purposes of classification is doubtful. As a rule, public corporations still perform "public services." But it is recognized today that public bodies may on occasion exercise private functions or act in a private capacity, ${ }^{23}$ while on the other hand, "public services" may be performed by private corporations or institutions. ${ }^{24}$ According to a more recent definition by Marcel Waline, the établissement public is an entity of public (administrative) law which is both decentralized and specialized in its functions. ${ }^{25}$ The implications of this definition deserve closer examination.

\section{Public Law "Personality"}

The fact that the établissement public is an artificial "person" of public law signifies primarily that it is a subject of legal rights and duties and endowed with a special fund which is not entirely integrated into the state budget. This aspect distinguishes the corporate institution from administrative services which are entrusted, by way of concession or in some other form, to private individuals. The creation of such public law "persons" regularly requires legislative or at least executive action. ${ }^{26}$

R.D.P.1955.716, note Waline; Jan. 13, 1958, Berry, R.D.P.1959.128. However, the expansion of this category was immediately checked by other courts, C.C., Oct. 30, I957, Veuve Radux c. ville d'Asnic̀res, D.1958.J.424; C.E., March 21, 1958, Sieur Salin, R.D.P.1959.122, concl. Bernard. Compare De Laubadère, La notion et le régime juridique des services publics sociautx en droit administratif français, Dr. Soc. 494 (1959). For a résumé of the judicial attitude, see WaLine 629 ( $\$$ I063); DE Laubabère 24. See also Morange, Le déclin de la notion juridique de service public, D.1947.Chron.XII.45; Waline, Vicissitudes récentes de la notion de setvice public, Rev. Adm. No. 5, 23 (1948); E. Lop, Essar sur LA Notion DE Service Public en Droit administratif Français (1949); J. L. De Corail, La Crise de la Nơtion Juridique de Service Public en Droit Administratif Français (1954); L'Huiliticr, $A$ propos de la "crise" de la notion de service public, D.1955.Chron.XXII.xI9; Nouvelles réflexions sur le service public, D.1957.Chron.XVI.9I.

${ }_{23}^{3}$ C.C., Civ. rre, Nov. 17, I954, Soc. civile du domaine de Dreux, D.1955.J.77, note Lavau (public body employing private law procedures for recovery of debt); C.E., May I4, 1948, Jacquin, R.D.P.1949.600, note Waline (private law contract concluded by municipality for performance of fire works); July 18, 1936, Epoux Faure, Rec.p.800 (exercise of patria potestas over orphans by office of public assistance); Oct. I6, I935, Dame Madaud, Rec.p.938 (provisional administration of property of mental patient by office of public assistance); June 19, 1918, Soc. des voiliers français, Rec.p.597 (capacity of public administration to conclude private law contracts); July 3I, I9r2, Soc. des granits des Vosges, Rec.p.909, S.r917.3.15, concl. Blum (similar). On this area of gestion privée, see Waline 70, 80-83 (\$5 I09, I3I-I33); DE LaUbadìre 32-33; I VEDel, Dr. AdM. 22.

24 Sce notes 232-40 infra.

26 Waline 353 (\$ 594). R. Connois, La Notion d'Établissement Public en Droit Administratip Français (I959), adopts a somewhat broader definition according to which the établissement public is a public organism (that is, any organism subject to some governmental authority) endowed with legal personality and dedicated to a special purpose (at $3 I$ ). While his arguments are impressive because of their logical rigor and perhaps are acceptable as guidelines for future reform, they are hardly in agrecment with present practice. In determining whether or not a body is an établissement public, recent decisions concentrate primarily on internal organization and modes of operation, C.E. Dec. 13, 1957, Barot, Rec.p.675; other criteria are the origin and nature of the revenues, the objectives of the body, and the statutory basis. Compare T.C., Nov. 23, 1959, Soc. mobilière et immobilière de meuneria, R.D.P.1960.676, note Waline, La distinction des établissements publics administratifs et industriels, et la possibilité, pour un établissement administratif de faire des opérations commerciales. On the general concept, see also M. Flutre, Essai sur ia Notion d'Etablissement Public (I945).

${ }^{20} \mathrm{~A}$ similar governmental action, however, may on occasion create private law corporations or associa- tions. For instance, in the case établissements d'utilité publique such as the National Savings Movement (ordinance of Oct. 13, 1945) or various municipal savings banks; or in the case of national companies 
Formerly, according to the Law of July I3, I925, national établissements publics could only be created by a law "which determines their objective, their principles of managment and confers on them legal personality and, as the case may be, financial autonomy."27 This requirement has been modified by the Constitution of the Fifth Republic. According to Article 34 of this Constitution, the Legislature has to establish the rules "concerning the creation of categories of établissements publics."28 In comparison to the previous regulation, the constitutional provision is at the same time more restrictive and more liberal: it is more rigid in that it prohibits the creation by executive decree of all categories of établissements publics, even of those not national in character; it is more lenient in that it permits the executive organs to create new établissements publics, even if they are national, as long as they come within the province of a "category" established by law. In November 1959, the Constitutional Council ruled that the creation of a single établissement public may amount to the creation of a new category if the character of the particular institution does not fit into existing schemes determined by law. ${ }^{20}$

Due to the "public" character of the établissements publics, their organization and functions are regularly governed by rules of administrative law. The organs of these bodies are entitled to render administrative decisions of a self-executing character which, however, are subject to the control of supervising authorities and may be attacked through action for annulment (excès de pouvoir) before administrative courts. $^{30}$ Thus, in collecting a debt, organs of the corporation may issue writs of attachment which require the debtor either to pay or to contest his obligation immediately in court. Within the limits established by the Legislature, the établisse-

such as the National Railway Corporation or the Credit Institute of the Ivory Coast (decree of Feb. 4, 1955); see WALINE, 255 ( $(4 \mathrm{II})$ and 355 ( $\$ 598)$. On the other hand, corporations which today are recognized as "public" may have had a private origin; e.g., the former French Law School at Cairo; see note 242 infra.

${ }^{27}$ Law of July $x_{3}, x_{925}$, art. 205; id. at 357 (\$ 60I); 2 JèzE, op. cit. supra note 16 , at 29. According to a law of Aug. I7, I948, administrative public corporations, but not commercial public corporations could be abolished by decree; C.E., Nov. I6, 1956, Union syndicale des industries aéronautiques, J.C.P.x957.2.9968, note Blaevoet, D.1956.J.759, concl. Laurent. The Constitution of 1958 abrogated this provision.

${ }^{28}$ This article has to be viewed in conjunction with Article 37 , according to which matters not reserved for the Legislature can be regulated by executive or administrative orders.

${ }^{20}$ Conseil Constitutionnel, Nov. 27, I959, R.D.P.1960.xor8-20, x022-24, note Waline, held that the establishment of the Autonomous Transport Direction of Paris constituted by itself the creation of a category of établissements publics. At the same time, the Council decided that "rules concerning the creation of a category," in the terms of Article 34, are those which form a constitutive or essential element of the organization of a public corporation. Consequently, rules determining the total number of members of the administrative council of the Transport Direction and the number of representatives of local authorities in this council were held to be of a regulatory character within the meaning of Article 37.

${ }^{30}$ C.C., Req., May 9, r953, Durif, D.H.I933.3I4 (ordinary courts have no jurisdiction to review such decisions of corporate organs); also C.E., April 20, I95I, Fauquier, Rec.p.204 (involving decisions of Atomic Energy Commission, a public corporation created by ordinance of Oct. I8, 1945, law of Aug. $\mathrm{r}_{3}$, I947). Only in very rare instances are private associations entitled to render self-executing decisions; compare C.E., Oct. 29, 1952, Delsuc, Rec.p.478 (concerning French Union of Veterans' Associations). 
ment public may levy taxes and other contributions. ${ }^{31}$ At the same time, although public corporations enjoy certain fiscal privileges, they are subject to taxation as soon as they have independent revenues or other sources of income. ${ }^{32}$ If the public interest so demands, public corporations may exercise the power of eminent domain. ${ }^{33}$ Also, works executed by such corporations or in their name have regularly the character of public works (travaux publics). ${ }^{34}$ By virtue of provisions of the Code of Civil Procedure, public corporations are unable to make compositions with debtors or resort to arbitration. ${ }^{35}$

The applicability of administrative law to public corporations has the further result that their personnel normally possess the status of civil servants or "public agents." ${ }^{36}$ As a rule, legal disputes between corporations and employees or third

${ }^{31}$ C.E., Dec. 20, 1935, Soc. des établissements Vezia, R.D.P.1936.13I, concl. Latourneric. However, in some cases, private corporation's and associations are also sustained by fiscal resources; see WaLiNE 358 (5 602).

${ }^{32}$ C.E., May I and Dec. 4, I93I, Chambre de commerce de X, D.1932.3.I7, note Trotabas. Sec also Chalandon, L'imposition des collectivités et des établissements publics, REV. DE SCIENCE ET DE LEGISLATION FinANCik̀RES I62 (I933).

${ }^{33}$ C.E., June 29, I95I, Lavandier, S.r951.3.91.

34 C.E., April 12, r957, Mimouni, Rec.p.262.

${ }^{\text {sc }}$ Code of Civ. Proc., arts. 83 and roo4; of. 2 Veder, Dr. AdM. 466; also T.C. May x9, 1958, Soc. Myrtoon Steamship et Cie v. l'Etat, D.1958.J.699, note Robert, L'aptitzde de l'État et des établissements ou organismes publics à l'arbitrage de droit privé, et la délimitation des compétences administrative et judiciare.

${ }^{36}$ C.E., Dec. 24, 1937, de la Bigne de Villeneuve, D.H.1938.185 (concerning public corporation attached to the state); Jan. 7, 1947, Devaux, J.C.P.1947.4.61 (concerning département or municipal corporations). C.E., June 4, 1954, Affortit et Vingtain, Rec.p.342, concl. Chardeau, D.r954.Somm.65, established the important rule that all employees of public corporations are placed in a public law relationship even if their employment contract does not contain a clause exceeding the regular confines of the general law, as long as their functions permit them to participate directly in the performance of the public service of the corporation. See also C.E., April 20, 1956, Epoux Bertin, Rec.p.I67, concl. Long, R.D.P.I956.869 and II45, I957.I01, note Waline; July 5, 1957, Evrard, Rec.p.446, concl. Tricot; Feb. 21, 1958, Bergey, Rec.p.120, R.D.P.1958.579; March 21, 1958, Sieur Salin, R.D.P.1959.122, concl. Bernard; March II, I959, Grimaldi, R.D.P. 1959.803; March 20, I959, Lauthicr, concl. Bernard, R.D.P.I959.770; Nov. 4, I959, Goett, R.D.P.1960.372; T.C., Jan. 13, 1958, Chardon, D.1958.J.412, note Blaevoet; Nov. 23, I959, Bruneaux, R.D.P.1960.349; Nov. 23, 1959, Demoiselle Santelli, R.D.P.1960.708. Private employment contracts therefore exist only where the application of private law was stipulated in the employment contract, or where the employment is so definitely auxiliary or menial as to exclude participation in the performance of the public service; C.E., Dec. 23, 1955, Dame de Fresquet, Rec.p.605; Jan. 20, 1956, Dombret, R.D.P.1956.676. The decisive criterion is not the designation or nature of the work itself, compare C.E., April 13, 1956, Chambre de commerce du Mans et de la Sarthe, Rec.p.632, with T.C., Jan. 13, 1958, Chardon, R.D.P.1958.579, D.1958.J.412, note Blaevoet (involving two types of "moniteurs"), also, C.E., Oct. 8, I958, Fornaresio et Morara, R.D.P.1959.359, with Feb. 25, 1959, Hôpital-hospice de Bernay, R.D.P.1959.780 (involving different kinds of hospital employecs); nor is it the temporary character of the work, compare C.E., March 16, 1955, Dame Stella Martin, Rec.pp.718,786, May 27, 1957, Mathais, Rec.p.353, with C.E., Nov. 2, 1956, Maurisset, Rec.p.412, June 26, x957, Pichot et Allin, Rec.pp.88I,927; nor the mode of remuneration, C.E., Jan. 13, 1958, Chardon, Rec. p.789; nor the place in the employment hierarchy, C.E., Nov. 28, 1958, Lepouse, D.1959.J.263; rather, it is the possibility of participation in the performance of the public service of the institution, C.E., May II, I959, Dame Climaque, R.D.P.I959.1071; March 20, I959, Lauthier, concl. Bernard, R.D.P.1959.770. On the right of public employees to strike, compare C.E., July 7, 1950, Dehaene, S.1950.3.109, D.1950.J.538, note Gervais, J.C.P.r950.2.5681, concl. Gazier, R.D.P.r950.69r, note Waline (in the absence of statute, government can stipulate limitations of this right in order to prevent abuses and safeguard the public interest; but limitations are subject to review by administrative courts); Nov. 28, 1958, Lepouse, D.1959.J.263, note Quermonne, R.D.P.1959.306 and 360, note Waline; June 10, 1959, Syndicat national des personnels des préfectures, R.D.P.1959.107I; Oct. 26, I960, Syndicat général de la navigation aérienne, R.D.P.I96r.I8r; see also Mankiewicz, Right to Strike of Civil Servants and Employees in the 
persons come within the jurisdiction of administrative courts and are adjudicated in accordance with substantive administrative law. ${ }^{37}$ Agreements executed by public corporate bodies usually have the character of administrative contracts, i.e., contracts which may contain clauses exceeding the confines of the general or civil law, especially provisions granting monopoly rights or exacting special penalties. ${ }^{38}$ This does not mean, however, that public corporations may not conclude civil law contracts or act in other ways like private individuals subject to the general civil law. ${ }^{38}$ If damages are caused by the activities of the public corporation, tort claims are tried before administrative courts on the basis of administrative law. ${ }^{40}$ Liability in such cases lies with the corporation itself rather than the supervising authorities. The relations between the public corporation and the users of its services are also regularly governed by administrative principles in the sense that users are entitled to equal treatment ${ }^{41}$ although a certain degree of discrimination may be justified in the public interest. ${ }^{42}$

Public Services, Under the French Constitution of 1946, 4 AM. J. Comp. L. 89 (1955). On the concept of "public agent," see WALINE 630 ( $\$$ 1065), 776 f. ( $\$ \S$ I633 f.); 2 VeDEL DR. ADM. 483 ff; D. Ruzí,, Agents des Personnes Publiques et Agents des Personnes Privées (1960); T.C., Nov. 23, 1959, Demoiselle Santelli, D.1960.J.280, note de Laubadère, Les agents de l'Administration et la nature de leur contrat; caractères distinctifs du contrat administratif de l" "agent public."

${ }^{37}$ T.C., Dec. 9, I899, Syndicat du canal de Gignac, S.I900.3.49, note Hauriou; C.E., May 29, I959, Goehrs, R.D.P.x959.1020; T.C., April 20, 1959, Demoiselle Salle, R.D.P.I959.I020. For delimitation of jurisdiction of administrative and ordinary courts compare also C.E., July 4, I958, Gayard, R.D.P.I959. 138 .

${ }^{38}$ Administrative contracts are characterized either by their nature, e.g., permitting the contractor to participate in performance of public service, C.E., July II-15, r960, Comp. industrielle des Bois de Clerval, R.D.P.1961.396; T.C., Nov. 23, 1959, Demoiselle Santelli, R.D.P.1960.708; C.E., Dec. 4, 1959, Sieur Delmas, R.D.P.x960.708; Jan. 23, 1959, Commune d'Huez, R.D.P.I959.I060; Nov. 14, 1958, Union meunière de la Gironde, R.D.P.r959.335; or by referring to execution of public works, C.E., Nov. 6, 1959, Auguste, R.D.P.1960.347; Nov. 4, 1959, Fourcade, R.D.P.r960.709; T.C., Nov. 3, 1958, Compagnie d'assurances L'Union, R.D.P.1959.335; or by the fact that they contain clauses exceeding the regular confines of common law, T.C., Nov. 14, 1960, Soc. anonyme commerciale agricole v. O.N.I.C., R.D.P.I961.397; C.E., Nov. 25, I959, Soc. nouvelle d'exploitation des plages, piscines et patinoires, R.D.P.r960.709; Jan. 23, I959, Lacombe, R.D.P.I959.780; T.C., Nov. 3, I958, Préfet de l'Aube v. Décesse, R.D.P.1959-354. On administrative contracts and the so-called clazses exorbitantes du droit commun, see WaLiNe 82 (\$ I32), $524 f f$. ( $\$ 892 f f),$.530 ( $\$ 900)$; DE LaUbadère 33.

${ }^{30}$ C.E., June II, 1948, Jouvet, D.I948.J.537, note Blaevoet. Compare note 23 supra; see also J. lamareue, Recherches sur l'Application du Droit Privé aux Services Publics Administratifs (1959), review Roche, R.D.P.I960.894.

${ }^{60}$ T.C., May 23, x908, Joullié, S.r909.3.49, note Hauriou; July 1o, 1907, Gillet, ibid. and Rec.p.643; C.E., March 8, 1907, Affaire Commune de Félix-Faure, ibid., and Rec.p.228. Responsibility for damages caused to users of vacation camps organized by public institutions is traditionally tried before administrative tribunals, T.C., March 3I, 1950, Gavillet, D.r950.J.33I, concl. Dupuich; C.E., July I7, I950, Delcasso, D.1950.Somm.67; July 3, 1953, Etesse, Rec.p.355. In recent years, the Tribunal of Conflicts held that the ordinary courts had jurisdiction here, as the relations between vacation camps and users were analogous to civil law relations. T.C., Jan. 22, 1955, Naliato, Rec.p.614, R.D.P.r955.7 6 , note Waline. But other courts reasserted the jurisdiction of administrative courts in similar situations; e.g., C.C., Oct. 30, 1957, Veuve Radux v. ville d'Asnières, D.r958.J.424. According to a statute of Dec. 3I, 1957, actions for recovery of damages caused by cars or other vehicles belonging to "persons" of public law come within the jurisdiction of ordinary courts; T.C., Nov. 14, 1960, Compagnie des bateaux à vapeur du Nord, R.D.P.1961.377; May 25, r959, Lecarme, R.D.P.r959.102r.

${ }^{\prime 1}$ C.E., June 6 , I947, Union catholique du diocèse de Versailles, S.1948.3.27. The right to equal treatment is one of the three principal rules characterizing a public service which Louis Rolland deduced from available court decisions: (I) the rule of continuity, or of uninterrupted performance of the service; (2) the rule of mutability, or of the adaptation of the service to technical and social progress; (3) and the 
In the administration of their funds, public corporations are subject to budgetary rules and principles of public accountability. ${ }^{43}$ Consequently, all expenditures of établissements publics must be based on the provisions of a budget which has to be set up at the beginning of each year by duly authorized organs of the corporation. All financial transactions are subject to the administrative supervision of public auditors (contrôleurs d'Etat) ${ }^{44}$ and to an annual judicial examination by the Audit Court (Cour des Comptes).45 Due to the public character of their budget, the assets of public corporations are exempt from seizure, forced sale, or any other form of legal attachment. ${ }^{46}$

\section{Decentralization}

As a "decentralized" corporate body, the établissement public is not entirely integrated into the general administration; and its operation is thus distinguished from services directly performed by the state or by its territorial subdivisions. Above all, the établissement public enjoys a considerable degree of financial autonomy. This means that it has its own budget, and that the expected revenues and expenditures are determined by the administrative organs of the corporation rather than by the general budget of the state as finally approved by the Legislature. ${ }^{\mathbf{4 7}}$ As a result of their financial autonomy, public corporations are able to dispose of any amount of their revenues not spent during a fiscal year by transferring it to the following year's budget. This possibility of saving and self-financing obviously acts as an incentive to careful and economical management. Financial autonomy also has the advantage of encouraging donations and legacies of wealthy individuals who are frequently more willing to entrust their contributions to the special fund of a corporation rather than to the state where the amalgamation of all revenues might divert the gift from its purpose.

The decentralized or autonomous character of public corporations and of their funds makes it possible for their organs to execute contracts or other agreements with the state. Similarly, public corporations are able to acquire rights against the

rule of the equality of users of the service. See Rolland, Notions générales sur les services publics, Les COURS de Droit (r940); WaLine 626-628 ( $\$ \S$ 1058-1061). For the rule of equality, compare C.E., Dec. 17, 1958, Soc. anonyme des distilleries Cornic, R.D.P.I959.348; Jan. 21, 1944, Darmon, Rec.p.22 (annulment of a numerus clausus); Dec. 29, I9II, Chomel, D.I914.3.5 (postal administration not entitled to require an individual to collect his mail at the post office).

${ }^{40}$ C.E., July Ir, 1960, Soc. des Phosphates Tunisiens, R.D.P.196r.387; March 15, 1946, Odilon Platon, Rec.p.79. As a rule, special tariffs must correspond to special situations and must be offered to all individuals placed in such situations or willing to accept derogation from usual tariffs; C.C., Civ., August 5, 1946, S.N.C.F., D.I946.J.393; C.E., Nov. I7, 1943, Etablissement Tiflex, Rec.p.26o; July I, I936, Veyre, Rec.p.713.

${ }^{13}$ E.g., decree of Dec. Io, 1953; Warine 354 ( $\left.\$ 596\right)$.

"Law of Oct. 25, 1935; ordinance of Nov. 23, 1944.

16 Law of April 4, 194I. With respect to general financial control of public corporations attached to the state, see decree of Oct. 9, I954 (No. 54.I008).

${ }^{48}$ C.C., Comm., July 9, I95I, Soc. nat. des entreprises de presse, J.C.P.195r.2.6437; Seine, Oct. I8, I933, Office nat. du tourisme, D.I934.2.65, note Waline.

${ }^{47}$ Items of the corporate budget appear in the state budget only in cases where the corporation receives state subsidies for the balancing of deficits. 
state, ${ }^{48}$ appear as plaintiffs in their own names, and even litigate against the state. At the same time, as has been pointed out, financial autonomy also entails the separate financial responsibility of public corporations ${ }^{49}$ in the sense that the state and its territorial subdivisions are not responsible for the liabilities of public corporations except in cases where such responsibility has been formally assumed by contract or where a quasi-delictual obligation arises out of negligence in the exercise of supervisory functions. Widespread misconceptions concerning this aspect of responsibility were among the principal factors which in I935 enabled Stavisky to perpetrate an enormous swindle with the "bonds" of the Municipal Credit Institute in Bayonne, a public corporation. In the Stavisky case, the Council of State ruled that neither the state nor the municipality as such were responsible for the liabilities of the credit institute. However, in view of negligence in the exercise of their supervisory functions, both state and the municipality were held liable in tort (quasi-delict)..$^{50}$

As can be seen, decentralization or autonomy of public corporations does not imply complete absence of control or supervision. In fact, all public corporations are subject to some form of government supervision ${ }^{51}$ by being attached either to the state itself or to one of its territorial subdivisions. In this sense it is possible to distinguish between national, provincial (départemental) and municipal or county corporations. The supervising territorial administrative agency is entitled to participate in the designation of the organs of the public corporation, and to supervise, in a broad manner, its administrative and financial management. The supervising authority is not necessarily determined by the locality in which the corporation exercises its functions. Thus, corporations located in a département or municipality may very well be subject to state control..$^{52}$ Rather, the classification of corporations as national, provincial or municipal depends on the organ exercising the power of supervision and tutelage. ${ }^{53}$ In some instances, public corporations may be attached to the supervising authority of other public corporations, such as syndicates of municipalities or local communities. ${ }^{54}$ The power of control and supervision is

${ }^{48}$ C.E., Dec. I, 1950, Électricité de France, S.r95r.3.6r, note Boulois, D.r952.J.642, note L'Huillier. This case involved an "industrial" public corporation; but the principle is applicable to all public corporations.

${ }^{10}$ C.E., April I, I938, Soc. de l'hôtel d'Albe, Rec.p.34r.

${ }^{\circ}$ C.E., March 29, 1946, Caisses d'assurances sociales du département de Meurthe et Mosselle, R.D.P.1946.490, concl. Lefas, note Jèze, S.I947.3.73, note Mathiot; Dec. 20, 1946, Pardini, Rec.p.3Ir.

61 C.E., Nov. 20, I908, Chambre de commerce de Rennes, S.I9I0.3.I7, note Hauriou. The principal exceptions to this rule are the chambers of commerce; C.E., Feb. 2I, 1936, Retail, S.1936.3.I2I, note Alibert, D.1936.3.7, note Gros. There is also an international public corporation, the Franco-Swiss Airport at Basel-Mühlhausen, established by the Franco-Swiss Convention of July 4, 1949. See Hahn, International and Supranational Public Authorities, supra, at 638-65.

"E.g., veterans' offices (decree of May Io, x947) and teachers' colleges located in the various départements (decree of April 24, 1948) are state corporations.

${ }^{63}$ C.E., Oct. 28, r938, Veuve Alaize, Rec.p.80r. According to Connois, the distinction between national and local public corporations rests upon different forms of administrative approval of financial accounts. Connois, op. cit. supra note 25 , at I5I ff.

5* Thus, municipal credit institutes (decree of May 20, 1955), municipal hospitals (law of Dec. 2I, I94I, decree of April I7, I943), and other bodies may be attached to syndicates of municipalities; see WALINE $362(\$ 608)$. 
greatly increased in cases where, due to insufficiency of revenues and budgetary deficits, the public corporation has to solicit state subsidies. Demands for such subsidies are not infrequent and seem to have multiplied in recent decades. ${ }^{.5}$ In such cases, budgetary appropriation has to be approved by Parliament, with the result that the theoretical autonomy of the public corporation is greatly overshadowed if not replaced by centralized management.

\section{Specialization}

Functional specialization distinguishes the établissements publics from territorial corporate bodies such as départements or municipalities, which perform a great variety of services. ${ }^{\text {b6 }}$ As a rule, the function or objective of a public corporation is narrowly circumscribed. However, there are some public corporations-such as chambers of commerce or syndicates of municipalities-whose functions are, at least to a degree, more diversified. Functional specialization implies that the corporation cannot engage in activities or use its funds for purposes alien to its particular objective. Any attempt to undertake such activities invariably results in annulment by administrative courts. ${ }^{57}$ Similarly, a public corporation cannot accept donations or contributions for purposes outside the scope of its special functions. ${ }^{\text {68 }}$ Also, the public corporation cannot maintain a court action concerning matters unrelated to its legal purpose. ${ }^{69}$

\section{Examples of Etablissements Publics}

An almost infinite number of corporate bodies are today classified either by statute or by judicial decision as établissements publics. Public corporations operate in practically every field of public concern, such as agriculture and commerce, finance, national education and art, public health, social security and public welfare, construction, city planning, public works, and transportation, information and com. munication, national defense and veterans' administration, and various other fields. ${ }^{00}$ The great majority of public corporations are attached either to the state or to

Et According to Drago, state subsidies granted during 1953 to public corporations (excluding "industrial" public corporations) amounted approximately to 50 billion francs. Drago, The Public Corporation in France, in W. Friedmann (Ed.), The Public Corporation I13, 125 (I954).

${ }^{50}$ Compare V. H. RIPERT, Le Principe DE Spécialité (I906).

${ }^{67}$ C.E., May 15, 1959, Dame Duchemin, R.D.P.r959.1057 (acquisition of buildings and furniture for the purpose of reunions, lectures, and festivities is outside the functions of municipal school funds); Dec. 13, 1939, Séguinaud, D.H.1940.79 (annulment of decision taken by a welfare office to run a motion picture theater in order to increase revenues); May 22, 1903, Caisse des écoles du VIe arrondissement de Paris, D.Ig04.3.I, concl. Romieu, S.rg05.3.33, note Hauriou (municipal school funds, established for the purpose of encouraging enrollment in public schools, cannot be used for public welfare objectives, e.g., by assisting needy children attending private schools).

${ }_{58}$ C.E., August 10, I9I7, Commune de Vivonne, Rec.p.634.

${ }^{60}$ C.E., June 4, I954, Ecole nationale d'administration, S.r954.3.96, Rec.p.338, concl. Chardeau (the teaching function of the National School of Administration prevents the latter from bringing action directed against a change in civil service regulations).

${ }^{60}$ For a list of the major public corporations in France, grouped according to their fields of activity, see WaLINE $377-80$ ( $\$ 635$ bis). A list of "national" public corporations may be found in CoNsois, op. cit. supra note 25, at 221-38. For an' older list of public corporations, grouped according to their attachment to supervisory authorities, see Hauriou, Prf́cis 24I-45. 
municipalities and counties, while only a comparatively small number of corporations operate under the supervision of départements.

The principal corporations attached to the state are the following: state hospitals; ${ }^{\text {ed }}$ national schools and other educational or cultural institutions, such as the College of France and college faculties, ${ }^{62}$ universities, ${ }^{63}$ secondary schools, ${ }^{64}$ state teachers' colleges, ${ }^{65}$ the National School of Administration, ${ }^{68}$ the National Conservatory of Music, ${ }^{67}$ the national libraries, ${ }^{88}$ the National Scientific Research Center, ${ }^{69}$ various national museums and national theatres; ${ }^{70}$ agricultural and commercial institutions, such as the chambers of agriculture ${ }^{71}$ and of handicraft ${ }^{72}$-but not the chambers of commerce ${ }^{73}$ - the National Institute of Original Designations (I.N.A.O.) $;^{74}$ institutions for public works, such as "authorized syndical associations"; ${ }^{75}$ various "offices," such as the National Immigration Office, ${ }^{76}$ and the National Office of Navigation; ${ }^{77}$ state banks, such as national deposit and savings

${ }^{01}$ Ordinance of Feb. 21, I84I, decrees of June I2, 1912, and Nov. 5, 1952.

02 Decree of July 25, I885, law of Dec. 31, 1932, decree of June 18, 1935. On the Institut de France, composed of the five great Academies, see Conwors, op. cit. supra note 25, at 134 f.

sa Laws of April 27, 1893 , and July 10, 1896, decree of July 3I, 1920.

o6 Decree of March 17, 1808, law of March I5, 1850, decrees of Sept. 28, 1908, and Aug. 27, 1943.

${ }^{06}$ Law of July 19, 1889, decree of April 24, I948; for Ecoles normales supérieures, see the laws of Feb. 3, 1953, and April 10, 1954.

${ }^{\circ 0}$ Ordinance of Oct. 9, 1945, decree of Feb. 20, 1946.

${ }^{\circ 7}$ Laws of Dec. 3I, 1942 and Oct. $7,1946$.

${ }^{09} \mathrm{Law}$ of April 29, I926, decrees of Sept. 12, 1927, and March 5, 1928.

o Ordinance of Nov. 2, 1945, decree of Junie II, I949 (formerly Scientific Research Fund, law of July I4, I90I); see C.E., Feb. 28, I95I, Syndicat national de la recherche scientifique, technique et atomique, Rec.p.Iz3.

${ }^{70}$ E.g., Union of National Lyrical Theatres (law of Jan. I4, 1939) and the National Theatre of the Comédie Franģaise (decrees of Oct. I2, I812, April 27, 1850, Feb. 27 and April 23, 1946). The question as to whether theaters could be public bodies or perform a public service was formerly the object of a vivid debate. The courts denied this possibility, and Hauriou protested strongly against the conception of a theater exercising a public service; see note to C.E., April 7, I916, Astruc, S.I916.3.49. Since 1923, however, judicial attitude has changed and admits that national theaters such as the Opéra, Opéra-Comique, and Comédie Française, perform a public service of a cultural character; C.E., July 27, I923, Gheusi, R.D.P.I923.60 and 566, note Jèze, concl. Mazérat. Compare WaLINE 623 ( $\$$ ro54); JÈzE, op. cit. supra note 16 , at 17 n.I, 33 n.2.

${ }^{71}$ Law of Jan. 3, 1924, decree of Dec. 8, x928; cf. C.E., Oct. 5, 1960, Ass'n permanente des Présidents des Chambres d'agriculture, R.D.P.x96r.391; July I, 1960, same litigant, ibid.

${ }^{72}$ Law of July 26, I925.

${ }^{70}$ Laws of July 23, 1820, April 9, 1898, and Feb. I9, I908, decrees of Sept. 3, 185I, June I4 and Sept. 28, I938. Even though the decree of $185 \mathrm{I}$ described the chambers of commerce as établissements d'utilité publique, their character as établissements publics has been recognized at least since 1885 , C.C., Req. Oct. 28, I885, Cazentre, S.I886.I.437; but they are no longer subject to state supervision. See note 51 supra, and Connols, op. cit. supra note 25 , at 158-60.

${ }^{74}$ Decree of July 16, 1947. The Institute (formerly National Committee of Original Designations, law of July 30, I935) participates in the recognition and protection of wine designations. Its character as a public corporation was recognized in C.E., Nov. I3, 1959, Navizet, R.D.P.r960.ro34, concl. Heumann, De la notion d'établissement public; des conséquences de cette qualification sur les litiges concernant les agents de ces établissements (held that I.N.A.O. constitutes an établissement public because of its organization and management, especially the appointment of its personnel, its fiscal revenues, it exercise of administrative prerogatives, and its submission to the Audit Court).

${ }^{72} \mathrm{Law}$ of June 2I, I865; T.C., Dec. 9, I889, Association syndicale du canal de Gignac, S.I900.3.49, note Hauriou. See note 96 infra.

${ }^{70}$ Ordinance of Nov. 2, 1945, decree of Nov. 26, 1946.

${ }^{77}$ Laws of Feb. 27, I9I2, and Nov. II, 1940. According to T.C., Feb, I0, I949, Guis, Rec.p.590, the functions of the Office are of a two-fold character: they are either administrative public services (e.g., 
banks $^{78}$ and institutes administered by these banks, the Autonomous Amortization Bank, ${ }^{70}$ the National Social Security Fund, ${ }^{80}$ and other financial and insurance institutions; the Legion of Honor; ${ }^{81}$ and the National Center of Cinematography ${ }^{82}$

Corporations subject to supervision by the départements are some mental hospitals and psychiatric clinics, various welfare offices, ${ }^{83}$ agricultural offices and chambers, département museums, ${ }^{84}$ and, of a more recent date, département syndicates for the protection against fire. ${ }^{85}$ On the municipal level, public corporations include municipal hospitals and clinics, ${ }^{86}$ local welfare offices and bureaus of public assistance, ${ }^{87}$ primary school funds, ${ }^{88}$ municipal credit institutes, ${ }^{80}$ local museums, ${ }^{00}$ "syndicates" of municipalities or counties, ${ }^{91}$ and "sections" of municipalities or counties. ${ }^{22}$ In addition, there are corporate bodies attached to other public

where the Office simply guarantees the orderly access of internal waterways to all users) or "industrial or commercial" public services (e.g., where the Office performs activities which are of a certain cconomic value to particular users, such as towage of ships through channels). See Waline 77 (\$ 124).

${ }^{78}$ E.g., Caisse des dépots et consignations, laws of April 28, 1816, and April 6, 1876; Caisse nationale d'épargne, laws of April 9, 188x, April 8, r910, Dec. 3x, 1948. Cf. C.E., June 29, 1906, Lurton, Rec.p.585.

7. Laws of April 29, and August 7, 1926.

${ }^{80}$ Ordinance of Oct. 4,1945 , decree of June $8,1946$.

${ }^{81}$ Law of Floréal 29, Year $X$, ordinance of March 26 , I816, decree of March 16,1852 . Although appointed by governmental decree, members of the Legion are not as such civil servants or public agents; litigation concerning their appointment or status, therefore, does not come within the original jurisdiction of the Council of State, C.E., Oct. r, 1958, Général Noguès, R.D.P.r959.337; nor docs it necessarily come within the appellate jurisdiction of that court, C.E., March 9, I960, Noguds et Chayrou, R.D.P.x960.863. See ealso, C.E., June 24, r960, Grand Chancelier de la Légion d'Honncur, R.D.P.I96x.I77.

${ }^{83} \mathrm{Law}$ of Oct. 25,1946 , decree of Dec. $28,1946$.

${ }^{83}$ Lav of August IO, I871.

86 Law of April 16, 5895 .

${ }^{85}$ Decree of May 20, 955 (No. 55.6r2). This decree enables the prefect and the departmental council to create a departmental public corporation for the purpose of assisting municipalities whose personnel and revenues are insufficient to combat fire damages. The organs of the corporation are an administrative commission, composed of three departmental councilors, three mayors, and four experts, with the prefect as the executive organ:. The budget of the corporation is voted by the administrative commission; its revenues derive from obligatory municipal payments, departmental contributions, state subsidies, and other sources. The corporation may be considered as an obligatory syndicate of municipalities. Sce WALINE $369(\$ 622)$. On the basis of a decrec of Nov. 5, 1926, syndicates of départements can be established, resembling in their organization the syndicates of municipalities; see Haurjou, PrÉcrs ÉLEM. 135. A major example of public corporations comprising several départements are the so-called "economic regions"; see 2 VEDEL, DR. ADM. 467.

${ }^{80}$ Laws of Jan. 22, April 8, and August 7, I851, Dec. 2r, 194r, decree of April 17, 1943. Cf. C.E., Jan. 21, Igro, Leplat, Rec.p.47.

${ }^{87}$ Decree of June I7, I852, law of July 15, I893, decree of Feb. 2, I955 (No. 55.r90). There are also so-called "Low-rent Housing Offices," established on the basis of laws of Dec. 5, I922, and July $21,1950$.

${ }^{88}$ Laws of April ro, I867, and March 28, 1882 . Primary schools as such are not public corporations. On the legal character and purpose of primary school funds, see C.E., May 22, 1903, Caisse des Ecoles du VIe arrondissement de Paris, D.rg04.3.r, concl. Romieu, S.x905.3.33, note Hauriou.

${ }^{80}$ Laws of June 24,1851 and Oct. 16 , 1919, decree of Oct. 24, 1918. Their legal character as public corporations has been recognized since C.E., June 20, I919, Brincat, S.r924.3.43. Compare Plytas, Nature juridique des monts-de-piété, 2 Rev. GEnfrale d'Administration, 5 (I912); Connois, op. cit. supra note 25 , at 166 .

${ }^{80}$ Law of April $16,1895$.

${ }^{91}$ Laws of March 22, I890 and Nov, 13, 1917. On the organization of these syndicates and on the recent creation of "mixed syndicates" and "urban districts" see notes rog-rII infra.

${ }^{82}$ Law of July I8, 1837 . These bodies are simply parts of a municipality which are endowed with a separate fund and whose purpose consists in the safeguarding and managing of this fund. Regularly the 
corporations, such as the joint local government corporations created by syndicates of municipalities. ${ }^{93}$

Apart from the differences in supervision and control, one may distinguish between établissements publics which are foundations, i.e., institutions basically characterized by their special fund, and those which are actual associations of a number of persons. The majority of établissements publics belongs to the first category. Among "associational" corporate bodies, the following are of major importance: the chambers of commerce, of agriculture, and of handicraft; ${ }^{94}$ the National Grain Office; ${ }^{95}$ and the authorized syndical associations of landowners.96Doubtful in this respect is the classification of the syndicates of municipalities or counties, since these syndicates do not constitute a new territorial collectivity, but merely a corporate institution for the execution of a special function. The mentioned "associational" bodies are treated by the courts as regular établissements publics $^{97}$ and, as such, have the same administrative rights and obligations as other public corporations. 98 Their organs have the power to issue regulations of a pro-

fund is managed by the municipal council itself; occasionally, however, a special organ called "syndical commission" is established for this purpose. See WAIINE $395\left(\$ 66_{3}\right)$.

${ }^{93}$ See note 54 supra.

o6 See notes 7r-73 supra.

${ }^{05}$ Office National Interprofessionnel des Céréals (O.N.I.C.), laws of Aug. 15, 1936, and Nov. I7, I940; formerly Wheat Office (Office du Blé), law of August 15 , 1913. The Office handles primarily the distribution of import licenses. According to T.C., Nov. 23, I959, Soc. mobilière et immobilière de: meunerie, R.D.P.1960.676, the Office is an administrative public corporation which, however, may perform activities or services of an industrial or commercial character; litigation concerning these services comes within the jurisdiction of the ordinary courts. Similarly, contracts executed in the commercial area are private law agreements subject to the jurisdiction of ordinary courts; C.E., Jan. 20, I960, Coopérative agricole de la région Clermont-d'Oise, R.D.P.I960.1047; T.C., Nov. I4, r960, Soc. Coopérative agricole de stockage de la région d'Ablis, R.D.P.I96r.337; unless such contracts contain clauses, exceeding the confines of private law, C.E., Dec. 21, I960, Favier, R.D.P.196r.338. Compare also C.E., Dec. 4, 1959, Groupement national des fabricants régionaux d'aliments pour le bétail, R.D.P.1960.365 (in distributing import licenses Office does not have the status of "commerçant"); June 29, 1960, Grison, R.D.P.196r.388.

${ }^{00}$ Syndical associations for the performance of special tasks can be traced back to the Middle Ages. The modern history of such associations dates from the statute of June 21,1865 . Subsequent statutes. have introduced modified regulations for particular associations, e.g., the laws of Oct. II, I940, May I6, 1946, and August 18, 1948, for associations concerned with the reconstruction of devastated regions or communities. Other syndicates are concerned with swamp clearance, protection against floods or forest: fires, and other tasks. Sometimes associations are created by voluntary agreement and retain a completely private character, subject to a minimum of administrative supervision. Where a minority of landowners is opposed to the creation of a needed association, the prefect may establish a compulsory or "authorized" association; even where a majority is opposed, the prefect may create a "forced" association on the basis of a decree of Sept. 26, I953. "Authorized" and "forced" associations are public corporations subject to administrative control and endowed with administrative prerogatives, such as compulsory membership, C.E., Feb. 13, 1953, Assoc. synd. de la digue de Paramé, S.I953.3.47; the power of eminent domain, C.E., June 29, I95I, Lavandier, S.I95I.3.9I; and the right to levy taxes, C.E., June II, I95I, Procureur, Rec.p.305; July 20, 1932, Ponnan, Rec.p.745. Furthermore, the funds of these associations are exempt: from legal attachment; their personnel may have the status of civil servants, C.E., April 25, I9r3," Mouche, Rec.p.457; and works executed by them are regularly public works, C.E., Jan. rx, r946, Assoc.. synd. du lotissement du quartier des Arènes, Rec.p.r2. Cf. WaLINe 370-377 (\$\$ 624-635).

${ }_{07}$ T.C., Dec. 9, I899, Assoc. synd. du canal de Gignac, S.I900.3.49, note Hauriou; C.E., July 26, 1935. Clément et comité de défense des usagers du marché réglementé de Paris, S.r936.1.4I, note Mestre.

${ }^{88}$ Some writers, it is true, distinguish "associational" bodies from other public bodies, and treat the. former as private or semi-public corporations; e.g., Pépy, L'extension des fonctions de l'Etat, ro ENcycL.Française Nos. I0-46 (1935). 
fessional or functional character and to levy contributions on all members in a semifiscal manner.

\section{Organization and Management}

Public corporations possess their own administrative organs which, although subject to superior control, enjoy a considerable amount of autonomy. The principal organ common to most public corporations is a governing board which may be designated as administrative commission, agency, or council, and which legally represents the corporation. In some instances, as in the case of hospitals, clinics, and chambers of commerce, the governing board is the only existing organ and combines both deliberative and executive functions. More frequently, however, the board is supplemented by an executive office-sometimes headed by a directorgeneral-which controls the staff of the corporation and is regularly subject to the supervision of the governing board. ${ }^{99}$ In some rare instances, finally, the corporation does not possess a governing board and is managed entirely by an executive director.

Methods of selecting the governing board are far from uniform. Frequently, the members of the board are simply appointed by the government or a territorial administration. In many cases, members are selected either in toto or in part by direct or indirect election. The latter method obviously introduces a further element of "decentralization" into the management of a corporation. Decentralization in this sense usually characterizes the "associational" public corporations, ${ }^{100}$ but is by no means limited to these bodies. In the case of hospitals and clinics, at least some members of the administrative committee are elected by the municipal council. ${ }^{101}$ The university councils are directly elected by the various faculties, while the deans of faculties are appointed by the government on the basis of preceding elections. ${ }^{102}$ Where syndical commissions are instituted for the administration of municipal sections, membership is based on election. The committees of syndicates of municipalities are directly elected by the municipal councils, while the governing boards of chambers of agriculture, commerce, and handicraft as well as the committees of syndical associations of landowners are elected by the compulsory syndicates or professional associations. ${ }^{103}$ The president or chairman of the respective boards may be appointed by the government; sometimes he is designated ex officio, such as the mayor or prefect in the case of hospitals or colleges, and the rector of the academy in the case of universities. In most "associational" bodies, the chairman is elected by and from among the board members. ${ }^{104}$

\footnotetext{
${ }^{99}$ Hauriou, Précis 246 n.I.

${ }^{100}$ Where the corporation is not based on a collectivity or social group, Vedel prefers to speak of mere "deconcentration" rather than "decentralization"; see 2 VEDEL, DR. ADM. 468.

${ }^{102}$ According to laws of Dec. 20, I94I, and Nov. 20, I943, hospital committees are presided over by the mayor and include representatives of the municipal council, the medical profession, and social insurance funds.

102 See DE LAUbaditre $2 \mathrm{r}_{3}$.

${ }^{108}$ Hauriou, PrÉcis 245-246.

${ }^{10}$ Drago, The Public Corporation in France, in W. Friedmann (ED.), The Public Corporation Ir3, I20-2I (1954).
} 
A similar variety of methods can be found in the selection of executive organs of public corporations where these organs are separate and distinct from the governing boards. In the majority of cases the executive organ or director is appointed by the government or a territorial subdivision of the state. The executive organs of "associational" corporations, however, are regularly selected by the governing boards. As previously mentioned, both the administrative organs and the regular staff of public corporations have the status of civil servants, ${ }^{105}$ although corporations may employ additional personnel by private employment contract. ${ }^{108}$ Since 1946, the employees of public corporations-like other civil servants-are entitled to form collective staff associations. As a result, administrative and technical committees have been formed in all public corporations. These committees act in an advisory capacity in connection with the administrative and functional management of the corporation. ${ }^{107}$

In view of their growing importance, syndicates of municipalities are frequently used by text-book writers for purposes of illustration. ${ }^{108}$ The establishment of such syndicates results from a voluntary act of the participating municipalities. ${ }^{108}$ However, there is the additional requirement of administrative permission which can be granted by the prefect in the case of municipalities located in the same département, and by the Council of State in the case of municipalities belonging to different départements. ${ }^{110}$ The syndicates have two major organs: a managing committee,

${ }^{205}$ See note 36 stupra. In the case of public corporations attached to the state, this status has been recognized by the Civil Service Law of Oct. 19, I946.

${ }^{100}$ Compare C.C., Civ., Oct. 25, I948, Piotet v, Bernier, D.I949.J.42.

${ }^{107}$ Compare C.E., Feb. 28, I95I, Syndicat national de la recherche scientifique, technique et atomique, Rec.p.r23 (involving National Scientific Research Center). Concerning requirement of regular consultation of comités techniques paritaires see C.E., March 6, 1959, Assoc. générale des administrateurs civils, R.D.P.I959.805; Oct. 22, I958, Rode et Syndicat national des personnels des bases aériennes, R.D.P.1959.359.

${ }^{108}$ See Waline 365-370 ( $\$ \$ 614-623$ ); Hauriou, Précis 25I-254.

100 The fact that the law of 1890 left the creation of syridicates to the voluntary initiative of the municipalities has kept the number of these corporations for a long time at a minimum. Gradually, syndicates were formed for purposes of road construction, electrification, and water supply. The Vichy regime attempted to establish compulsory, or non-voluntary, syndicates; but this procedure was abandoned after the Liberation. As previously mentioned, the département corporations for protection against fire, established since May 20, 1955, come close to being compulsory syndicates of municipalities. The direct creation of compulsory syndicates has been made possible recently by two ordinances of Jan. 5, 1959. According to the first (No. 59.29), the Minister of the Interior after consultation with the département council can establish a syndicate if this step is supported by the municipal councils of at least two-thirds of the municipalities concerned, representing more than half of the total population of the latter; or by half the municipalities, representing two-thirds of the population. Still greater prerogatives have been conferred upon the government by the second ordinance (No. 59.30) concerning the establishment of "urban districts." Such districts can be created either in the forms provided by the first ordinance, or without municipal support by decree of the Council of State; in the latter case, the government can even impose unequal representation of municipalities in the syndical council. Under a decree of May 20, 1955, as amended by ordinanice of Oct. II, I958, municipalities are able to. associate not only among themselves, but also with other territorial bodies and even with public corporations in so-called "mixed syndicates." Compare WAIINE 369-370 and Annex 23-24 (\$\$ 6I7, 621, 623, 623 bis). The recent proliferation of territorial syndicates is criticized by Vedel as endangering the principle of decentralization. 2 VEDEL, DR. ADM. $48 \mathrm{r}$.

${ }^{110}$ Hsuriou, Prtas 252. Compare C.E., June 22, 1906, Flicoteaux, Rec.p.572. Syndicates can be dissolved by the government if their objective is attained; C.E., Jan. I5, I943, Commission admin. de l'hôpital intercomm. d'Aulnay-sous-bois, Rec.p.r. 
and an executive office or bureau. The committee is composed of members elected by the municipal councils of the participating municipalities, with each municipality being entitled to two delegates. Changes in the ratio of representation require the express consent of all syndicated municipalities. ${ }^{111}$ The qualifications for eligibility are the same as those for municipal councilors. The term of office coincides with the term of the electing municipal council; but re-election of committee members is possible. The committee elects its own president who implements committee decisions and represents this public corporation in court. At least two regular committee sessions are held each year, mainly for the purpose of drawing up the syndical budget. The bureau, which is elected annually by the committee from among its members, exercises delegated executive functions and has to report to the committee at the beginning of each regular session.

\section{B. Professional Corporations}

\section{x. Introduction}

In recent years, especially with the consolidation of professional organizations, writers and courts have come to recognize that établissements publics are not, or no longer, the only category of non-territorial public corporations in France. The recognition of a separate category of professional public corporate bodies seems to be inspired by the desire to exempt these bodies from the more rigid juridical regime of the établissement public, and more particularly by the vehement opposition of liberal professions against any form of bureaucratic domination. On a limited scale, professional organizations of a special public law character can be traced back to the Consulate and the Napoleonic Empire. Since that time, disciplinary chambers of various quasi-judicial officers-such as notaries-public, solicitors, auctioneer-valuers, and bailiffs-have existed in France. These chambers although recognized as legal entities of public law, have never been treated as établissements publics. ${ }^{112}$ The idea of professional organization received new impetus during the present century with the rise of syndicalism, and especially with the establishment of corporative institutions under Fascist regimes. The Vichy government followed this trend and, between I940 and I944, created organization committees ${ }^{113}$ and a number of professional corporations, such as the Corporation of Physicians. ${ }^{114}$

After the Liberation, the provisional government immediately abolished most

${ }^{111}$ C.E., April 28, 1950, Commune de Lombez, Rec.p.238. In the case of "urban districts," however, the government can decree unequal representation of the communities.

${ }^{213}$ See WaLINE $38 \mathrm{I}$ ( $\left(6_{37}\right)$. Due to the quasi-judicial functions of their members, the disciplinary activities of these chambers remain subject to the jurisdiction of ordinary courts. Decisions concerning internal organization; however, are administrative acts and within the competence of administrative courts; C.E., June 9, 1950, Chambre syndicale des experts en objets d'art, Rec.p.355 (involving auctioneer-valuers); Oct. 19, 1934, Jolivet, D.r935.3.32, concl. Latournerie (involving solicitors). With respect to the principle that judicial acts are subject to the jurisdiction of ordinary courts compare C.E., Nov. 9, 1960, Dame veuve Devens, R.D.P.r96r.339; June 12, 1959, Dame Crozes, R.D.P.I959.1019; March 4, 1959, Decoux, R.D.P.1959.780; Jan. 2, 1959, Demoiselle Lachenaud, R.D.P.1959.780; Oct. 22, 1958, Ramaroni, R.D.P.r959.334.

${ }_{118}^{112}$ Law of Aug. 16, 1940; see De LAubadìre 36.

114 Law of Oct. 7 , 1940. 
of the professional corporations established by the Vichy regime. However, other professional bodies were speedily re-established, frequently on the basis of statutory provisions closely resembling the Vichy regulations. ${ }^{115}$ In addition, new corporate bodies were created in several liberal professions between I945 and I947. At present, professional corporations in France comprise the corporations of physicians, surgical dentists and midwives, ${ }^{118}$ barristers, ${ }^{117}$ public accountants, ${ }^{118}$ pharmacists, ${ }^{110}$ veterinarians, ${ }^{120}$ architects, ${ }^{121}$ and land surveyors. ${ }^{122}$ The legal nature of these bodies has been clarified by the Council of State in a famous decision of $1943^{123}$ which held, first, that professional associations perform a public service; ${ }^{124}$ secondly, that their organs possess some administrative prerogatives and are thus at least in certain respects administrative or public law authorities; ${ }^{\mathbf{1 2 5}}$ and thirdly, that the associations are not établissements publics. The political significance and desirability of professional corporations, of course, remains debated and debatable. It can hardly be denied that a reactionary kind of corporatism, such as practiced under Fascist regimes, entails the danger of a feudalization of society. But defenders of professional corporations argue that these bodies, deriving originally from progressive syndicalist and socialist ideas, are an adequate means for the advancement of professional efficiency and for the furthering of professional representation. ${ }^{128}$

\section{Public Law Personality}

The legal personality of professional organizations is in some cases directly stipulated by the act establishing the corporation. In the absence of such a direct provision, legal personality results clearly from the capacity to sue and be sued and

${ }^{116}$ Compare J. Berthon, Les Ordres Professionnels (thesis, Paris, 195i); Ph. Biays, La Fonction Disciplinare des Ordres Professionnels (thesis, Rennes, 1949); Liet-Veaux, La theorie des établissements professionnels et les élections aux conseils des Ordres, Rev. Adu. No. I4, I53 (1950).

${ }^{116}$ Ordinance of Sept. 24, 1945, as amended by law of April I9, I951.

117 Compare regulation of April ro, 1954.

${ }^{118}$ Ordinance of Sept. I9, 1945, as amended on May 29, I947, June II and Oct. 8, I95I, and Sept. 23, $195 \%$. (1946).

${ }^{210}$ Ordinance of May 5, 1945. Compare Doublet, L'Ordre national des pharmaciens, DR. Soc. 99

${ }_{120}$ Law of Aug. 23, I947, as amended by law of Feb. 25, I953.

121 Decree of April 19, 1945.

${ }^{123}$ Law of May $7,1946$.

${ }^{123}$ C.E., April 2, 1943, Bouguen, S.I944.3.I, concl. Lagrange, note Mestre, J.C.P.I944.2.2565, note Célier (Corporation of Physicians). Compare also C.E., July 31, 1942, Monpeurt, D.Crit.1942.138, concl. Ségalat (Organization Committees; the decision did not directly touch upon the public or private character of these Committees, but their character as public organisms was stressed by Ségalat).

${ }^{134}$ As the Council specified, the public service of the medical corporation does not consist in the exercise of the medical profession but in the organization and control of the profession.

${ }^{130}$ Among legal writers, Connois is most emphatic in rejecting the "public law" character of professional corporations and in classifying them as private organisms engaged in the performance of certain public services. Connors, op. cit. stspra note 25 , at $100 \mathrm{ff}$., 213. This attitude is somewhat surprising in view of the fact that Connois does not hesitate to consider "public enterprises" and even "national societies" as public corporations (établissements publics). See id. at I $88 \mathrm{f}$. and I95 ff. It must be recognized, however, that professional bodies are in many respects more akin to semi-public corporations than to établissements publics. Their treatment in these pages as public corporations merely follows the Bouguen case, stupra note 123 .

${ }^{120}$ Compare Francois Perrovx, Capitalisme et Communaté de Travail (i938). 
the right to receive funds and donations. ${ }^{127}$.. That professional organizations are corporations of "public law" can be gathered from various factors, such as their performance of a public service and their creation by legislative acts or government decrees. More importantly, however, the "public law" character is manifested in compulsory membership and in the administrative prerogatives attributed to the organs of the professional organizations.

As regards compulsory membership, the principle is firmly established that nobody' may exercise his profession unless he has been entered in the official register of the proper professional corporation. ${ }^{128}$ Exercise of a profession without such registration constitutes a crime irrespective of the offender's professional qualifications. Similarly, retirement or dismissal from the professional corporation renders a person incapable of further exercising his profession. Registration or admission can be refused on various grounds specified in legislative acts or deontological rules; but competent organs frequently have considerable latitude here. ${ }^{120}$ Membership dues are levied on all members of the corporation in a compulsory and practically semi-fiscal manner.

Apart from compulsory registration and the levying of membership dues, the organs of the various professional corporations have very extensive disciplinary powers over their members. As a rule, disciplinary measures are based on professional codes of ethics or codes of deontology which regulate professional conduct both in relation to clients and in relation to other members of the profession. ${ }^{130}$ To the degree that

${ }^{127}$ Cf. art. 64 of the ordinance establishing the Corporation of Physicians; also art. I6 of the 1954 regulation concerning the Corporation of Barristers which recognizes the right to maintain court action.

${ }^{128}$ On admission or registration, compare C.E., May I4, 1943, Gremeau, Rec.p.122 (physicians); July 15, 1949, Husson, Rec.p.36o (architects); July I, I949, Bonnin, Rec.p.322 (same); June 29, r960, Hilaire, R.D.P.r96r.393 (public accountants); Jan. 19, I95I, Torgues, Rec.p.33 (same); April 26, 1950, Krupp, Rec.p.235 (same). Final decisions on admission are not judicial decisions; C.E., June 14, 1946, van den Veegaete, Rec.p.I67 (architects); March 3, 1948, Baudoin, Rec.p.IIo (public acc.); June 19, 1953, Grizard, Rec.p.304 (land surveyors); Dec. 12, 1953, de Bayo, S.1954.3.14, D.1954.J.294.

${ }_{120}$ C.E., May 2, 1959, Conseil National de l'Ordre des Médicins, R.D.P.Br959.1057 (physician changing his residence must be registered in the département of his new residence, and this registration can be refused if requirements of independence and moral conduct are not fulfilled even though the facts relied on may be antecedent to registration in the département of his former residence); Nov. 26, 1958, Leroy, R.D.P.x959.352 (registration may be refused on the basis of activities of applicant leading to conviction even though court sentence was eliminated by later amnesty law); April 2, 1952, Yves, Rec.p.203 (physicians; effect of conviction followed by rehabilitation); Oct. 19, I949, Kirchgessner, Rec.p.424 (same, followed by amnesty); Nov. I2, I949, Loctfer, Rec.p.479 (architects; verification of moral character); April 16, r947, Lambla de Sarria, Rec.p.145 (same); April 7, 1948, Borgne-Pérignon, Rec.p.150 (illegality of refusal without prior hearing); May 20, 1960, Lévy, R.D.P.1960.1065 (public accountants; where bias of national councilor was not asserted during registration proceedings, it cannot be invoked on appeal); May 16, 1952, Valliet, Rec.p.806 (conviction followed by rehabilitation); May 5, 1950, V'́rot, Rec.p.263 (pro-German attitude or similar acts covered by amnesty are insufficient reasons for refusal); March 5, 1947, Escribe, Rec.p.95 (incompatibility with other employments); July 28, 1952, Jozét, Rec.p.43I (land surveyors; refusal must be motivated).

${ }^{180}$ C.E., June 24,1960 , Hait-Hin, R.D.P.1961.393 (disciplinary sanction based on physician's acceptance of commercial publicity); March 25, I960, Boileau, R.D.P.r960.1065 (sanctions based on professional failures of physician); July 5, I959, Sicre, R.D.P.x959.r255 (refusal of architect to terminate litigation through amicable settlement cannot serve as basis of sanction). Codes of deontology have been established in the Corporation of Physicians by decree of June 27, 1947, as amended on Nov. 28, 1955; in the Corporation of Pharmacists by decree of June 25, 1953; and in other professional corporations. 
their organs participate in the enactment of codes of deontology, professional corporations clearly are endowed with a public law regulatory power. ${ }^{131}$ Disciplinary sanctions can be very severe. In some instances, especially in the Corporation of Physicians, the sanction may amount to expulsion from the profession because the offender is prevented from registering in any other territorial subdivision and thus from exercising his profession in any part of France. Moreover, in the Corporation of Physicians, a member of the Council of State is attached to the disciplinary chamber of the professional council, with the result that for purposes of appeal, disciplinary decisions are considered as judgments of an administrative tribunal..$^{132}$

It should be pointed out, however, that the extent of administrative prerogatives is not entirely uniform in the various professional corporations and that these prerogatives never equal the powers of an établissement public. The Corporation of Physicians is entitled to cite non-registered persons exercising the medical profession directly before the criminal courts, a power not shared by other organizations. Also, disciplinary decisions of the national medical council are judgments of administrative courts subject to appeal to the Council of State while, due to the judicial function of barristers, decisions of their corporate organs are regularly subject to appeal before the regular courts. ${ }^{133}$ Of greater significance is the fact that neither the organs nor the members of professional corporations have the status of civil servants. Contracts executed by the professional corporations or by their members regularly have the character of private law agreements unless they contain specific clauses exceeding the confines of private law. ${ }^{134}$ However, damages caused directly by these corporations may constitute government torts. ${ }^{135}$

Some of the deontological rules established by the Corporation of Public Accountants have been voided subsequently; C.E., July 15, 1954, Comité de défense des libertés professioninelles des experts-comptables, D.1955.Somm.13; July 19, 1950, same litigant, R.D.P.1951.212, concl. Odent, note Waline, REv. ADM. No. 17,47 I (1950), note Liet-Veaux, Dr. Soc. 391 (1950), note Rivero.

${ }_{101}$ The Corporation of Physicians, in collaboration with the competent minister, is also able to regulate the procedures through which a physician can establish himself as specialist and to limit or exclude the possibility of multiple specialization; C.E., July 15, 1959, Laidet, R.D.P.1959.1255. However, the basic zegulations concerning general practitioners are established by legislative and government enactments rather than by regulations of the medical association; C.E., June 26, 1959, Demoiselle Firstoos, R.D.P. 1959.1058. ${ }^{182}$ See WALINE $383(\$ 640)$. In some other corporations, disciplinary actions are also considered as judicial decisions; compare C.E., Jan. 5, r95I, Dame Faure, Rec.p.6 (pharmacists).

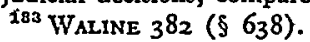

194 Thus, the relations between physicians and social security agencies employing their services are of a private law character and subject to the jurisdiction of the civil courts; C.E., June I2, I959, Berche, R.D.P.1959.ro20. The Corporation of Physicians requires the obligatory notification of the council of all contracts-including rent and lease-relative to the exercise of the profession; if such contracts are incompatible with the rules of the profession or with professional independence, the physician so contracting cannot be registered or remain on the register of the Corporation. In reviewing contracts executed by a physician, the national council is not required to consider his explanations or inquire into his motives; C.E., Nov. I9, 1958, Chadia, R.D.P.1959-352. Under a decree of June 4, 1957, doctors attached to public hospitals may receive a specified number of private patients in the hospital on the basis of a direct agreement on costs to be paid to the doctor; C.E., Feb. I9, 1960, Chambre syndicale des médecins de la Seine, R.D.P.rg60.86r.

${ }^{185}$ C.E. . Dec. 5, I947, Froustey, Dr. Soc. 60 (1949) (physicians); Oct. I, I954, Demoiselle Costier, J.C.P.1954.2,8446, note Savatier, DR. Soc. 8x (1955), concl. Laurent (surgical dentists); March 29, I957, Conseil nat. de l'Ordre des chirurgiens-dentistes, R.D.P.1957.1065, note Waline. 


\section{Organization and Competences}

Professional corporations are organized in various territorial councils, ranging from département and regional councils to a national council. Delegates in these councils are elected by and from among the registered members of the profession. ${ }^{\mathbf{1 3 0}}$ Decisions concerning registration are normally rendered by the département or regional councils, with the possibility of appeal to the superior council or councils and sometimes to administrative courts through action for annulment. Disciplinary competence ${ }^{137}$ regularly resides in the national council, but is sometimes distributed between regional councils acting as chambers of first resort and the national council as an appellate organ. Thus, in the Corporation of Physicians, registration is handled by the département council whose decisions can be appealed to the superior councils. ${ }^{138}$ Elections to the département council may also be challenged before the regional council. ${ }^{139}$ Disciplinary matters are decided by the regional council, with the possibility of appeal to the national council and ultimately to the Council of State.

\section{II}

\section{Semi-Public Corporations}

The corporations discussed so far, especially the non-professional public corporations or établissements publics, are not entirely the products of this century. Some of the principal types and distinguishing marks of these bodies have been established and elaborated during the early period of the Third Republic. Professional corporations, on the other hand, are reminiscent of medieval guilds and, in their modern forms, primarily serve the purpose of disciplinary supervision. Since the first World War, however, the state has become increasingly involved in new areas of activity which hitherto had been dominated by private initiative, and has encouraged the formation of new corporate bodies and associations in the economic and social domain. This trend was accelerated and broadened in France by the nationalization of war industries in $1936^{140}$ and by the great wave of nationalizations immediately after the Liberation. The avowed purpose of these nationalizations was the elimination of the former owners or "capitalists" from the control and management of enterprises which perform a "national public service," that is, a public service of national interest, or exercise some kind of factual monopoly. ${ }^{141}$ However, while the negative aim of the exclusion of capitalists from these sectors of the national economy was

\footnotetext{
${ }^{236}$ On elections compare C.E., Feb. 10, 1950, Comité de défense des libertés professionnelles des experts-comptables, Rec.p.98 (public accountants).

${ }^{137}$ On disciplinary measures compare C.E., Feb. 20, 1953, Demoiselle Armelin, Rec.p.88 (physicians); Feb. 18, x949, Viet, D.1949.Somm.I8 (architects); Feb. 16, 1951, Delaville, Rec.p.99 (pharmacists); Feb. 18, 1955, Offner, D.r955.J.224, concl. Laurent (public accountants).

${ }^{188}$ C.E., June 29, 1960, Kornfeld, R.D.P.I96r.I77; April 2, 1952, Yves, Rec.p.203.

${ }^{180}$ C.E., Jan. I9, I949, Deroide, Rec.p.22.

${ }^{140} \mathrm{Law}$ of August II, I936, decrees of Jan. I6 and $27,1937$.

${ }^{111}$ The preamble of the Constitution of Oct. 27, 1946 provided: "All enterprises whose conduct possesses or acquires the character of a national public service or of a factual monopoly shall become property of the community." $C f$. WALINE 637 ( $\$ \$$ ro67-68).
} 
comparatively clear, the positive aim, and especially the future legal and economic regime of nationalized enterprises was doubtful and controversial from the beginning.

The principal promoters of nationalization-especially the labor unions-were strongly opposed to the complete integration of nationalized industries into the public administration of the state. ${ }^{142}$ In their view, these industries were to be controlled by the "nation" rather than the state. This conception was quite vague and somewhat contradictory. A consistent policy of nationalization involves a concomitant transformation of the traditional "state" in the direction of a socialist welfare system. However, the conception inspiring nationalization in France admitted in effect the continuation of traditional liberal democracy, and of the dichotomy between the "state" and the private and social domain. One result of this continuation of the traditional "state" system was that the latter could attempt to bring the nationalized enterprises more and more under its own control and thus to substitute state socialism, or étatisme, for the policy of nationalization as originally envisaged by its sponsors.

More importantly and quite apart from this, the persisting dichotomy of state and private domain had as a result that the nationalized industries were placed in a strange, intermediary position, ${ }^{143}$ a semi-public and semi-private sphere, whose legal confines and implications were very difficult to assess. It is commonly agreed that the regime of nationalized industries ${ }^{144}$ and other semi-public enterprises is presently the most confused branch of French administrative law. Since I945, efforts have been made in legal literature, by court decisions, and even in some draft laws to unify and harmonize the legal status of the various industries and corporations, and to establish the concept of "public enterprise" as a common denominator. ${ }^{\mathbf{1 4 5}}$

142 Already in I920, the program of the C.G.T. stated: "In view of the impotence of existing political organizations and the character of their power, we do not wish to increase the functions of the state itself, nor strengthen a system which would subject the basic industries to a civil service regime with all its lack of responsibility and its serious defects, a process which would subordinate the forces of production to a fiscal monopoly." See Drago, supra note 9, at 129.

${ }^{148}$ Because of this intermediary position, the national enterprises have sometimes been denounced as another manifestation of "neo-feudalism" or "technocratic feudalism" and as symptoms of the contemporary decomposition' of the state. Contra, Maleville, L'autorité de l'État sur l'Électricité de France et Gaz de France, C.J.E.G. I40 (1953). Compare Rivero, L'évolution du droit des entreprises nationalisées (1946-1955), in M. Boiteux et aL., Le Fonctionnement des Entreprises Nationalisées en France 68-69 (1956) [hereinafter referred to as BoITEux ET AL.].

24t On nationalization in France, compare JeAN Rivero, Le REgime des Nationalisations (I949); Marjo Einaudi, Maurice Byt \& Ernesto Rossi, Nationalization in France and Italy (i955); BoiteuX et al.; C. G. De Loubresse, Le Rḱgrme Juridique des Entreprises Nationalisées (thesis, Montpellier, 1958); G. Lescuyer, Le Contrôle de I'État sur les Entrepruses Nationalisées (1959), review Drago, R.D.P.r960.419; bibliography cited in Waline 634 ( $\$$ I069).

${ }^{145}$ On Dec. 31, 1948, the government submitted a draft law concerning the status of "public enterprises" which attempted to distinguish between enterprises assimilated to commercial companies and enterprises dominated largely by public law; but the draft was never put to a vote. Cf. Virally, Remarques sur le projet de loi portant statut général des entreprises publiques, Rev. ADM. No. 16, 355 (1950). Subsequently, a law of April 3, I955 invited the government to submit a new draft law on public enterprises; but no action has so far been taken. See Waline 641 ( $\$$ ro76). The term "public enterprise" or "national enterprise" is widely used in legal literature. Compare A. G. DeLion, L'Etat ET les Entreprises Publiques (1958); L. Bredin, L'Entreprise-Sémi-publique et Publique (I957); Langrod, L'entreprise publique en'droit administratif comparé, REV. INTERNAT. DE DroIt COMPARÉ 2I3 (1956); A. Garrigou-Lagrange, L'Etat Producteur: Les Entreprises Publiques et SEmi-publiques 
However, these efforts have so far been unsuccessful; and as long as the Legislature does not act, the idea of "public enterprises" is bound to remain highly speculative.

Some of the industries and enterprises are treated either by the Legislature or by courts as public corporations of an industrial or commercial character (établissements publics commercials ou industriels). Other enterprises are frequently designated as national companies or national societies (sociétés nationales). These societies comprise "one man corporations" and "mixed economic" companies, i.e., enterprises in which the state has acquired either all the shares or at least a controlling part thereof. While enterprises of the first category are in many respects subject to administrative rules and thus are obviously semi-public in character, national societies can be described as semi-public only in the sense that, due to its ownership of shares, the state frequently exercises considerable control over the management of these companies. ${ }^{146}$

\section{A. Etablissements Publics Commercials ou Industriels}

\section{Historical Development}

After the first World War, administrative courts became increasingly aware of the expanding economic activities of the state. In rg2r, a famous decision of the Tribunal of Conflicts introduced the distinction - between "administrative" public services which are regularly subject to public law, and "industrial or commercial" public services which are primarily subject to private law, and only in certain aspects to administrative law. ${ }^{\mathbf{1 4 7}}$ This rough distinction did not entirely clarify the meaning of the concept of "industrial or commercial" public services. However, subsequent decisions have established that such services are activities which are performed by the state active "in the manner of a regular industrialist," 148 "in the forms of the general law"; 149 or which are industrial or commercial "by nature and

(1954); Saint-Geours, L'trat et les entreprises publiques, DR. Soc. 409 (1953). As another common denominator, Vedel has proposed the term "commerçant public"; see 2 VEDEL, DR. ADM. 469, 471-72, 482; also Le régime des biens des entreprises nationalisées, in BorTEUX ET AL. 209.

${ }^{14}$ "The use of the term "public" or "semi-public" does not imply that all the corporations or com. panies in the two categories perform a "public service" in the traditional sense. Thus, with the exception of four deposit banks, the so-called nationalization of credit and bank institutions has not altered the fact that these institutions exercise a commercial rather than a public function. In the case of the Renault enterprises (ordinance of Jan. I6, I945) and the Gnome ct Rhone aircraft corporation (ordinance of May 29, 1945, S.N.E.C.M.A.), nationalization was effected as a punitive measure for alleged collaboration during the Vichy regime and has not transformed these companies into public services. On' the other hand, some enterprises-e.g., electricity and gas companies-lad always been considered as public services and have simply retained this character after nationalization. Compare Waline 635-36 (\$ ro70); De Laubadère 234; 2 Vedel, Dr. AdM. 477, 481; Rossillion, Les entreprises publiques et la notion de service public industriel et commercial, L'ACTUALITE JURIDiQue No, 7, I, 4I (I956).

147 T.C., Jan. 22, 192r, Colonie de la Côte d'Ivoire (also called bac d'Eloka), S.1924.3.35, concl. Matter (where ferry operated by Ivory Coast colony had capsized and sunk, in view of the operation of the ferry service in the manner of an ordinary business enterprise, liability of state for damages was to be determined by the civil courts). Compare also C.E., Dec. 23, 1921, Soc. générale d'armements, R.D.P.1922.74, conel. Rivet (state insurance company). Under the decrees of Nov. 5 and Dee. 28, 1926, departmental and local authorities are similarly entitled to operate "commercial and industrial" services.

${ }^{148}$ C.E., Oct. 20, 1950, Stein, Rec.p.505; Feb. 6, 1935, Babon-Diago, Rec.p.157.

${ }^{140}$ C.E., Feb. 6, 1935, Boyer, Rec.p.157. 
performed in a manner not different from a private enterprise."150 Where services thus described are performed by a separate public body distinguished from the state and its.territorial subdivisions, courts at least since I933 have become accustomed to speak of "industrial or commercial public corporations." "151

Public corporations of this character multiplied in the pre-war years and during the Vichy regime. According to a financial survey of 1946 , state supervision at that time extended to various industrial or commercial public corporations operating in the financial field, such as the Agricultural Credit Fund and the National Fund for State Contracts; in the field of transportation, such as the autonomous port authorities of Le Havre, Bordeaux and Strasbourg; ; $^{152}$ in the areas of fuel and gasoline distribution, such as the Regie Autonome des Pétroles, and in chemistry, such as the Office of Alsacian Potash Mines. ${ }^{153}$ Since then, numerous other public corporations of a commercial or industrial character have been created as a result of nationalization laws. ${ }^{154}$ These corporations include primarily Électricité de France (E.D.F.) and Gaz de France (G.D.F.), ${ }^{155}$ the Coal Board of France, ${ }^{156}$ the National Society of

${ }^{160}$ C.E., Dec. 23, 1949, Soc. électro-métallurgique de Saint-Léger, Rec.p.569; Feb. 15, 1935, Soc. franc. de constructions mécaniques, D.H.r935.240, S.I935.3.86; April 15, 1935, Chambre de commerce de Lorient, Rec.p.529; Jan. 29, I932, Kuhn, S.1932.3.97, note Delvolvé. The qualification is usually not extended to services that do not involve commercial risks or produce economic benefits; C.E., June 30, r950, Soc. Merrienne, Rec.p.408; May 16, 1941, Toublanc, Rec.p.91. Compare WaLINE 77-79, 630 (\$\$ 123-126, 1065); Connors, op. cit. supra note 25, at 201 ff.; also Charlier, Le régime complexe des services publics industriels ou commerciaux, J.C.P.1955.I.I220; Blaevoet, Les services et les établissements publics à caractère indiustriel et commercial, D.r947.Chron.XIX.73; C. Chavanon, Essai sur la Notion ET le Régime Juridique du Service Public Industriel ou Commercial (i939).

${ }^{151}$ T.C., Nov. 27, 1933, C.E., Feb. 9, I934, Verbanick et Mabille, D.x934.3.9, note Waline. According to ConnoIs, op. cit. supra note 25 , at 206 , industrial or commercial public corporations are distinguished from administrative public corporations primarily by their internal structure and operation. Compare also T.C., Nov. 23, 1959, Soc. mobilière et immobilière de meunerie, R.D.P.I960.676, note Waline, La distinction des établissements publics administratifs et industriels, et la possibilité, pour un établissement administratif, de faire des opérations commerciales, where Waline emphasizes internal organization and operation; the source of revenues, the purpose of the institution, and the statutory basis.

${ }^{152}$ The establishment of autonomous port authorities dates back to laws of Jan. 5, I9I2, and June 12, 1920, and decrees of Nov. $3_{3}$, 1924; see HAuriou, Précrs 242; Connors, op. cit. supra note 25, at I62. According to a statute of April 26, 1924, the autonomous port authority of Strasbourg is subject to both state and municipal supervision; see WaLINE 362 ( $\$ 608)$; Connors, supra at I69-I7I. C.E., April I7, 1959, Abadie, R.D.P.1959.803, ruled that the autonomous port authority of Bordeaux performs both administrative and industrial or commercial services, and that its employees are therefore public agents or private workers, depending on the service to which they are attached.

${ }_{15 s}$ Regie autonome des pétroles, decrees of July 29, 1939, April 12, 194r, and Oct. 22, 1947; the Office national industriel de l'Azote (law of July $\mathrm{Ir}$, 1924, decrees of May 30, 1925, and July 30, 1936) may be considered as a forerunner of later "national enterprises," cf. I VEDEL, DR. ADM. 472.

${ }^{16}$ " Vedel prefers to differentiate between earlier industrial or commercial corporations and corporate bodies resulting from nationalization measures. Among the former, he distinguishes between corporations which were not directly concerned with commercial or industrial enterprises and others which were almost completely assimilated to commercial entities. See $i d$. at $471-72,478$.

${ }^{105} \mathrm{Law}$ of April 8, 1946, as amended by law of July 30, 1960 (No. 60.780), decrees of Aug. 29, 1949, and May 24, r950. The nationalization of electricity and gas involved a simple change of the grantee of the concessions, in the sense that the former distributing companies were deprived of their concession contracts and required to cede the latter to the new public corporations. The compensation of the former grantees was not always very satisfactory or equitable; see WaIINE 636 ( $\$$ Io66). Compare P. Benazet, L'Autorité de l'État sur les Entreprises Publiques du Secteur de l'Énergie (i958); Bliss, Nationalization in France and Great Britain of the Electricity Supply Industry, 3 INT'L \& CoMr. L.Q. 277 (I954); Roblot, La nationalisation du gaz et de l'électricité, DR. Soc. I79 (1946).

${ }^{186} \mathrm{Law}$ of May 17, 1946. The Coal Board of France (Charbonnages de France), a national public 
Press Enterprises (S.N.E.P.), ${ }^{157}$ and the National Office of Aeronautic Studies and Research (O.N.E.R.A.). ${ }^{158}$ To these nationalized enterprises one may add various corporations which have been created without nationalization, such as the Paris Airport, the Paris Transport Board, the Society of Biochemical Products, Agence France-Presse, ${ }^{159}$ and others.

\section{Legal Regime}

The legal regime of industrial or commercial public corporations displays a curious blending of public and private law. The past decade witnessed a gradual judicial expansion of the applicability of private law to the normal operations of these corporations, and to their relations with employees and users. ${ }^{i 00}$ This development is not entirely surprising, as this category of corporate bodies was originally created with the very intention of exempting their conduct as far as possible from the administrative strait jacket. The corporations here under review possess a separate legal personality, which, together with a broad conception of the "specialty" of their industrial or commercial functions, ${ }^{161}$ permits a considerable degree of autonomy and independence in business activities.

With the exception of management officials and executive directors, ${ }^{102}$ the per-

corporation, controls and supervises nine semi-autonomous mining districts (houilleres de bassin) which are also national public corporation's endowed with administrative organs. Since the establishment of the European Coal and Steel Community in 1952, the French coal corporations are again exposed to more competitive market conditions. Compare Gardent, Les Houillères françaises et la concurrence sur le marché de la Communauté Européenne du charbon et de l'acier, in Borteux ET al. 125; M. AldaIs, La Gestion des Houillères Nationalisees et La Theorie Economioue (1953); B. Garrigue, La REforme de Structure dans les Houmlères Nationalisées (1953); Personnaz, La nationalisation des houillères, $\mathrm{D}_{\mathrm{R}}$. Soc. $8 \mathrm{I}$, $12 \mathrm{I}$ (1947).

${ }^{157} \mathrm{Law}$ of May II, I946, decree of Dec. 8, I955 (No. 55.1609). Despite its designation as a "national society," the S.N.E.P. constitutes a "commercial or industrial" public corporation; C.C., Comm., July 9, r95I, S.N.E.P. v. Arthus, D.1952.J.141, note Blaevoet, J.C.P.1951.2.6437 (absence of lucrative purpose, performance of public service, exercise of administrative prerogatives, e.g., power to issue self-executory decisions for collecting debts).

${ }^{158}$ Law of May 3, 1946; but see ConNors, op. cit. supra note 25, at 207. A similar institution is the Centre scientifique et technique du batiment, decree of Sept. 30, 1953 (No. 53.983). The legal character of the Renault company is ambiguous since the ordinance of Jan. 16, I945, used merely the term "industrial and commercial corporation" which, according to Waline, "means absolutely nothing from a juridical point of view," WaLINE 64I ( $\$$ roj7); compare Vernier-Palliez, La Régie Nationale des Usines Renault devant la concurrence, in Borteux ET AL. 95; Myon, La politique de relations sociales d la Régie Renault, id. at 381 .

${ }_{159}$ Ordinance of Sept. 30, 1944, decree of Aug. 9, 1947, law of Jan. 10, 1957, decree of March 9, 1957 (No. 57.28I). Agence France-Presse is an industrial and commercial public corporation, with the result that litigation involving its personnel-with the exception of the director general-comes within the competence of the civil courts; C.E., March 8, 1957, Jalenques de Labeau, D.1957.J.378, note de Laubadère, S.1957.J.276, concl. Mosset; Paris, July 8, I957, Agence France-Presse, J.C.P.I958.2.10448, concl. Lindon, note Motulsky. Compare also C.E., March 13, 1959, Sieur Nègre, R.D.P.1959.809 (director general).

${ }^{160}$ See Rivero, L'évolution du droit des entreprises nationalisées, in Borteux ET AL. 52, 56; Conclusion, id. at 404 ; also Houin, La gestion commerciale des entreprises nationaliséees et le droit privé, id. at $217 \mathrm{ff}$.

${ }_{101}$ Concerning the capacity of the electricity, gas and coal corporations to perform a variety of services, compare Rivero, stpra note 160 , at 56-57.

${ }_{109}^{109}$ T.C., Feb. 22, I960, Lagarrigue, R.D.P.1960.836; C.E., March 13, 1959, Sieur Nègre, 
sonnel of these corporations are regularly employed by private contract and thus do not have the status of civil servants or public agents ${ }^{163}$ except in cases of direct performance of an administrative public service. ${ }^{164}$ Similarly, contracts executed by the corporation with its users or suppliers are private law agreements, ${ }^{185}$ unless special clauses or peculiar conditions of management transform the transaction into an administrative contract. ${ }^{166}$ As a rule, litigation between the corporation and its employees or users is consequently subject to the general law and within the jurisdiction of ordinary courts. ${ }^{167}$ The private law regime is also manifested in the relations between the corporation and other government agencies or public corporations, ${ }^{108}$ and in the fact that the decisions of organs of the corporation are usually not administrative actions and therefore outside the jurisdiction of administrative

R.D.P.r959.809; March 8, 1957, Jalenques de Labeau, D.I957.J.378, note de Laubadère, S.I957.J.276, concl. Mosset (leading case; director of Agence France-Presse); T.C., Jan. 17, 1955, de Postis du Houlbee, Rec.p.6rI (functions of a director "impress upon the legal relations of this agent to the state the character of a public law relationship").

${ }^{108}$ C.E., Dec. 16, 1959, Ranteannia, R.D.P.I960.373; July Ir, 1958, Demoiselle Limousin, R.D.P.1959.173; Dec. 26, I95I, Dame Hinard, Rec.p.61 8; C.C., Soc., July I2, I950, Ardouin, D.I950.J.665, note Blaevoet. The criteria for determining the private or public character of employment are not entirely uniform. Since industrial or commercial public corporations may perform administrative services, and vice versa, the character of the services performed was usually held to be decisive; e.g., C.E., Jan. 25, 1952, Boglione, D.I953.J.8. But since some employees participate in different kinds of services, reliance has frequently been placed on the character of the corporation; C.E., April 20, I95r, Fauquier, Rec.p.204; March 8, 1957, Jalenques de Labeau, J.C.P.I957.2.9987, note Dufau; Dec. 20, I957, Hamon, Rec.p.70I; July II, I958, Demoiselle Limousin, R.D.P.r959.I73. Nevertheless, the criterion of the services performed has not been completely abandon'ed; C.E., April 17, I959, Abadie, R.D.P.1959.803. On the general status of the personnel compare Mathiot, L'arrêt Jalenques de Labeau et la soumission au droit privé du personnel des services publics industriels et commerciaux, S.I957.Chron.43; Dufau, De la condition juridique du personnel d'Électricité de France et de Gaz de France, C.J.E.G. I, II (I957); Fusilier, Le statut du personnel des entreprises nationalisées comparé au statut des agents de la fonction publique, R.D.P.1956.50I; Levasseur, La situation du personnel dans les entreprises nationalisées, in BorTEUX ET AL. 337 ff.

${ }_{106}$ T.C., Feb. I0, I949, Guis, Rec.p.590.

${ }^{105}$ It is generally assumed that contracts for the performance of industrial or commercial public services may be private or administrative in character, depending on the absence or presence of clauses exorbitantes du droit commun. However, some decisions seem to establish a presumption in favor of the private character of contracts executed by industrial or commercial institutions; compare T.C., Feb. 22, 1960, Société Pétronaphte, R.D.P.r960.836.

${ }^{208}$ C.E., Oct. 20, 1950, Stein, Rec.p.505; Dec. 23, 1949, Soc. électro-métallurgique de Saint-Léger, Rec.p.569. The electricity and coal corporations have been enabled by the Legislature to repudiate prior long-term contracts concluded by the expropriated enterprises; see Rivero, L'évolution, in' Borteux ET AL. 59; De Laubadère 239, n.2.

${ }^{107}$ C.E., Dec. 20, 1957, Hamon, Rec.p.7or; Jan. 23, 1953, Mistral, Rec.p.32; Jan. 25, 1952, Boglione, D.1953.J.8; July 27, z95I, Bataille, Rec.p.435, and Réveille, ibid.; Feb. 6, I935, Babon-Diago, Rec.p.157; Nov. 8, r929, Mounier, D.I930.3.4I, note Bienvenue. The competent tribunals are frequently commercial courts, while the jurisdiction of labor councils (conseils de prud'hommes) is not entirely settled. The Court of Cassation had always rejected the competence of labor councils in regard to industrial or commercial public services. However, in 1950 , the court recognized their jurisdiction in the case of industrial or commercial public corporations deriving from nationalization measures; C.C., Soc., July I2, 1950, J.C.P.1950.2.5727. See Rivero, L'évolution, in Borreux ET AL. 59; Vedel, Le régime des biens des entreprises nationalisées, id. at $208 ; 2 \mathrm{DR}$. ADM. $47 \mathrm{I}, 476$.

${ }^{168}$ C.E., Dec. I, 1950, Electricité de France, S.195I.3.6I, note Boulouis, D.1952.J.642, note L'Huillier (E.D.F. may acquire rights against the state and, a fortiori, against a "mixed economic" society such as S.N.C.F.); August 4, 1928, Admin. des chemins de fer algériens de l'État, Rec.p.ro59. However, litigation between the corporation and superior and supervisory authorities belongs to the jurisdiction of administrative courts; C.E,, Nov. I7, r950, C.J.E.G. 89 (I95I), concl. Agid. Compare Blaevoet, Le contentieux des établissements publics industriels et commerciaux, R.D.P.1958.42. 
courts. ${ }^{169}$ As business enterprises, industrial or commercial public corporations are subject to taxation in the same manner as private firms. ${ }^{170}$ Damages caused by the corporation or its personnel to users or third parties regularly give rise to civil liability, with jurisdiction in the civil courts, ${ }^{171}$ unless the damages result directly from the execution of public works. ${ }^{172}$

Nevertheless, public corporations of a commercial or industrial character are not entirely assimilated to private enterprises. Due to their designation as "public" bodies, it has been held that at least some of these corporations do not have title to their corporate funds or assets. ${ }^{173}$ However, the question of ownership is very controversial. ${ }^{174}$ Again, in some instances, it has been decided that these corporations are not subject to attachment or execution. ${ }^{175}$ There is substantial agreement that

${ }^{109}$ C.E., July 3, 1953, Commune de Corps, Rec.p.346. Under a decree of Nov. 5, 1953, national enterprises are entitled to issue self-executory orders in recovering debts; 2 VEDEL, DR. ADM. 478.

${ }^{170}$ C.E., Dec. I7, I932, Min. des Finances, Rec.p.1103. On the other hand, fees or charges paid by users are not of a fiscal character and may be set by simple administrative action; compare C.E., Dec. 23, 1959, Jacquier et Camidessus, R.D.P.r960.36r (E.D.F.).

${ }_{171}$ C.E., March 13, 1959, Soc. Lyonnaise des eaux et du gaz d'éclairage, Rec.p.182, R.D.P.1959.1068; Nov. 4, 1955, Soc. Fruitière de la Chapelle Rombaud, Rec.p.523; T.C., June 24, 1954, Dame Galland et autres, Rec.p.7I7; C.C., Req., March 30, 1939, D.H.r939.302; T.C., July 1 , I935, Demoiselle Demangcon, Rec.p.r237; March 23, 1907, Roumens, Rec.p.3ri. Compare also C.E., March 4, 1959, Electricité et Gaz d'Algéric, R.D.P.x959.ro29.

272 Where damages are caused by installations of gas, electricity, or water supply services, administrative courts have jurisdiction over actions of third persons (since these are damaged by public works), while the civil courts are competent for actions of subscribed users of the services (since subscription contract is a private law agreement); C.E., Jan. 22, 1960, Sieur Gladieu, R.D.P.I960.686 and 734, concl. Fournier (G.D.F.). Compare C.E., May 13, I959, Ministre des P.T.T. et Gaz de France, R.D.P.r959.1046 (in the case of damages caused by gas canalization during installation works executed by government employee, liability rests in equal amounts with the state and with G.D.F.). On administrative jurisdiction in case of public works see also C.E., July 6, 1960, E.D.F. et Compagnie d'assurance L'Urbaine et la Seine, R.D.P.1961.376; July II, 1958, Electricité de France, Rec.p.436; Feb. 14, 1958, Soc. Thorrand et Cic., Rec.p.104; April I2, 1957, Mimouni, Rec.p.262; Oct. I9, 1956, Soc. Le Béton, Rec.p.375, R.D.P.I957.310, concl. Long; April 20, 1956, Min. de l'Agriculture v. Grimouard, Rec.p.x68, R.D.P.x956.ro58, concl. Long, note Waline; T.C., March 28, 1955, Effimieff, Rec.p.617; C.C., Crim., June 23, 1954, Séguer v. G.D.F., J.C.P.r954-2.836r, note Blaevoet; Civ., Nov. 2I, 1949, Compagnie élect. Loire et Centre v. Farizon, J.C.P.I950.2.55I7, note Cavarro; C.E., May I, I942, Soc. du Gaz et de l'Electricité de Marseille, Rec.p.143; Feb. 9, I940, Compagnic Européenne du Gaz, Rec.p.57.

${ }^{173}$ C.C., Comm., Jan. 29, I952, Electricité de France, S.1952.I.196 D.1952.J.737, note Derrida.

${ }^{174}$ The Council of State has remained very cautious in its language. Thus, in 1950, this court merely recognized a certain right of industrial public corporations to handle their assets, without specifying the character of this right; C.E., Dec. I, 1950, E.D.F.-S.N.C.F., S.1951.3.61, concl. Agid, note Boulouis, D.I952.J.642, note L'Huillier. On March 16 , I948, it was held that the capital of these corporations does not belong to the public domain, but to the private, fiscal domain of the state; S.r949.i.77,n.r. The applicability of the concept of public state property was also rejected by lower courts (Aix, Jan. 31, 1952, and Nimes, Feb. 12, 1952, J.C.P.1952.2.6860; Orleans, Oct. 23, 1952, J.C.P.I952.2.73I2). There is a definite trend to recognize the legal title of industrial public corporations and national enterprises in their assets. Vedel strongly contends that assets and funds are regular private property of these corporations or enterprises; Vedel, Le régime des biens des entreprises nationalisées, in BoITEUX ET AL. I93-204; also 2 DR. ADM. 479. While proceeding from the same premise, Blacvoet distinguishes between "public" corporate property attached to the exercise of a public service and "private" property unrelated to such a service. Blaevoet, stspra note 168 , at $20,40-42$. It is generally agreed that industrial public corporations can acquire and sell property. The right to rent or lease real estate or offices was formerly contested; C.C., Comm., June 8, 1953, E.D.F. v. consorts Rivalin, D.1953.J.481 (contra). But a decree of Sept. 30, 1953, extended the applicability of the commercial law of rents and leases to "public enterprises"; see Rivero, supra note 167 , at 58 .

${ }^{275}$ C.C., Comm., July 9, I95I, Soc. nat. des entreprises de presse, S.1952.I.I25, note Drago, 
works undertaken by industrial public corporations are public works. ${ }^{178}$ It is also agreed that corporations created pursuant to nationalization may issue self-executing orders for collecting debts. ${ }^{177}$ In recent years, industrial or commercial public corporations have been denied the right to make compositions with debtors or to resort to arbitration. ${ }^{178}$

Above all, the semi-public character of these corporations is demonstrated in the extensive intervention of the state and other administrative agencies for purposes of financial and administrative control. From the growth of this intervention during the past decade, Jean Rivero and other writers have deduced a basic dichotomy in the development of semi-public enterprises: increase of state supervision despite a concomitant expansion of the private law regime in ordinary business operations. ${ }^{170}$ Public control is particularly pronounced in the case of corporations directly supervised by the state, especially the great nationalized enterprises. Supreme political control over these institutions is exercised by Parliament itself, to which all financial accounts must be submitted. ${ }^{180}$ For this purpose, subcommittees are established in both houses of Parliament which are charged to "observe and examine"181 the management of the nationalized bodies, and which have the power of legislative

Administrative supervision is exercised by public control commissions which investigate the management of corporations, and by state inspectors in the case of corporations receiving state subsidies. ${ }^{183}$ All commercial or industrial public corpora-

D.I952.J.14I, note Blacvoet. Against the extension of this ruling to other corporations or enterprises see Vedel, supra note $x 67$, at 206. Compare also Rivero, supra note 167 , at 60 .

${ }^{176}$ See Blaevoet, supra note r68, at 29.

${ }^{177}$ Decree of Nov. 5, I953; of. note I69 supra.

${ }^{178}$ C.E., Dec. 13, 1957, Soc. nationale Vente des surplus, J.C.P.1958.2.1080o, note Motulsky, D.r958.J.517, note L'Huillier, C.J.E.G. IOI (1958), DR. Soc. 89 (1958), concl. Gazier. Cf. Vedel, 2 DR. ADM. 479-80; also Mazeaud \& Vedel, E.D.F. et G.D.F. ont-ils la capacité de compromettre?, C.J.E.G. 224 (I950).

${ }_{170}$ Rivero, stipra note 167 , at 52-53. According to Rivero, the conflict is solved or at least reduced by the ability and technical experience of management officials in the various corporations and enterprises. ${ }^{180}$ See Drago, supra note 9, at $\mathrm{x} 36$; Delion, Le contrôle des entreprises publiques, II: Le contrôle parlementaire, DR. Soc. 265 (1959).

${ }^{181} \mathrm{Law}$ of March 2I, I947.

investigation committees. ${ }^{182}$

${ }^{182} \mathrm{Law}$ of July 3, 1947. Each subcommittee was at first composed of 16 members; but a finance law of Dec. $3 \mathrm{I}$, I953, increased membership to 24 committeemen, half of whom had to belong to the Finance Committee. On Dec. 6, I957, the National Assembly further increased the number to 34, including 17 members of the Finance Committe. Under the Fifth Republic, an ordinance of Nov. I7, 1958 (No. 58.1100), provides for the establishment of new subcommittees, but of a temporary rather than standing character. The investigatory power of these committees was restrictively interpreted by a Council of State opinion of 1954 which held that corporations or enterprises could withhold professional secrets, secrets involving national defense or fabrication procedures, and any information the disclosure of which could damage the interests of the company; C.E., May I8, 1954, DR. Soc. I46 (1955). The Legislature removed these limitations by law of April 3, 1955 (No. 55.366), which extended the power of investigation to all technical, administrative, and financial activities, to past transactions, present operations, and future plans. See Lescuyer, Les entreprises nationales et le Parlement, R.D.P.I960.1165-66,1185; 2 VEDEL, DR. ADM. 475; Le contróle par les commissions parlementaires de la gestion des entreprises nationalisées et des sociétés d'économie mixte, DR. Soc. I37 (1955); Rivero, supra note 167 , at $64-65$.

${ }^{183}$ The economic and financial control powers of these commissions were greatly increased by decrees of May II, I953 (so-called "Laniel decrees"). Above all, state inspectors and heads of control commis- 
'tions are also subject to an annual financial examination by the quasi-judicial Audit Commission ${ }^{184}$ and by the "Court of Budgetary Discipline."185 In addition to these a posteriori controls, some activities or decisions of nationalized corporations require the prior consent of the competent minister or government official. Furthermore, in matters of land purchases and state contracts, special commissions for the "control of real estate transactions" and the "control of public contracts" have to be consulted. ${ }^{188}$ As in the case of public corporations, the exercise of state control is usually more rigid wherever state subsidies are furnished. ${ }^{187}$

\section{Organization and Management}

The organization of industrial or commercial public corporations closely resembles the structure of administrative corporations. This means that the major organ is usually a governing board called "administrative council," sometimes supplemented by an executive office or director general. For some time, the nationalized corporations had a peculiar feature of organization: the mixed composition of the governing board. The intermediary or semi-public character of these corporations had inspired at an early time the idea of tripartite management, ${ }^{188}$ i.e., the allocation of three numerically equal blocs of seats on the administrative council to $(\mathrm{I})$ representatives of the state as principal producer and consumer; (2) workers represented by labor unions; and (3) consumers organized in consumers' associations. Thus, the large electricity, gas, and coal corporations of France were managed by boards composed in equal parts of representatives of the government, labor unions, and consumers' organizations. However, during the past decade the formula of tripartism has gradually disappeared. Especially the representation of users and consumers has declined, making room for the expanding influence of state representation and control..$^{189}$

sions were armed with a suspenisive veto over all decisions of corporate organs. Heavily criticized in Parliament, these provisions were again abrogated by a law of April 3, I955 (No. 55.360); but the weakening of administrative control was immediately counterbalanced by the reinforcement of parliamentary supervision (law of the same day, No. 55.366). Compare Chenot, Direction et controble des entreprises nationalisées, in BorTEUX ET AL. $557-58$; Rivero, id. at $64-65$.

${ }_{184}$ Commission de vérification des comptes; law of Jan. 6, 1948. By decree of May 19, 195I, the regular financial control by the Audit Court (Cour des Comptes) was re-established for those public corporations which, despite their designation as "industrial or commercial," perform a "primary activity analogous to the activity of administrative public corporations." One such corporation is the former compensation and decentralization fund of the areonautic industry. See 2 VEDEL, DR. ADM. 471-72.

${ }_{185}$ According to a 1955 report of this Cour de discipline budgétaire (established by law of Scpt. 25, I948), only eight cases involving public enterprises had been examined and no sanctions had been imposed on the respective organs; see Chenot, supra note 183 , at $15^{8-59}$.

${ }^{186}$ Law of Sept. 26 and decree of Sept. 18, 1948. Compare Drago, sutpra note 9, at $x_{3} 6$; Chenot, supra note 183 , at 158 ; Rivero, supra note 167 , at 66 .

${ }^{187}$ For an estimate of state subsidies granted to some semi-public corporations and enterprises in 1953, see Drago, The Public Corporation in France, in W. Fruedmann (Ed.), The Public Corporation II3, 135 (I954).

${ }^{188}$ Already the program of the C.G.T. of $x 920$ stated: "By nationalization we mean that national property should be put under the control of those directly interested, the producers and consumers." See id. at I29; also DE LAUBADÈRE 238.

180 This development was particularly accentuated by the decrees of May II and Dec. 18, 1953, which 
The director general of industrial and commercial public corporations is normally appointed by the government upon the proposition of the administrative council. As a rule, the government also has a strong hand in the appointment or selection of the president or chairman of the administrative council. While council chairmen sometimes enjoy a theoretical or legal superiority, the factual power balance usually inclines to the side of the director general and other executive officials or experts. ${ }^{190}$ In the Fifth Republic, government influence on the appointment of management officials has been strengthened and expanded. ${ }^{191}$ As previously mentioned, staff members of industrial corporations are regularly employed by private contract and thus subject to private law. ${ }^{192}$ Since 1946, "staff committees" and "mixed production committees" have been established among the personnel of the electricity and coal boards, with consultative functions in regard to internal administration and commercial management. ${ }^{193}$

The operation of industrial public corporations in France has as a rule been highly acclaimed because of technical efficiency and productivity. ${ }^{104}$ The same cannot always be said of their internal administration and financial management. In internal administration, the growing influence of state control has largely overshadowed the original conception of tripartism. The serious problem of management-labor relations has also not been solved, and the envisaged transformation of employees from salaried workers into co-producers and co-managers has not been entirely successful. ${ }^{195}$ Regarding financial management, industrial public corporations-and especially nationalized enterprises-have not always been able to pursue their activities in an independent, business-like fashion. It is sometimes charged that the monopoly enjoyed by nationalized corporations has hampered their economic initiative, and that the tripartite or bipartite composition of the governing boards

strengthened the administrative and financial control of the state. See Lasserre, Aspects économiques des nationalisations frangaises, in BorreUX ET AL. 35; Rivero, supra note 167 , at 63 . The suppression of the representation of local organizations in the administrative councils of E.D.F. and G.D.F. by the decree of May II, I953, was upheld on the theory that a subsequent law of July II, I953, prohibiting the reduction of the same representation, was not retroactive; C.E., July 15, 1958, Ville de Lyon, R.D.P.I959.I70. Due to increased governmental influence on matters of representation; this period also witnessed the exclusion of C.G.T. representatives from most administrative councils; see Chenot, supra note 183 , at $\mathbf{5 5}$.

${ }^{100}$ In many cases-e.g., in the coal and electricity boards-a direct delegation of powers from the administrative council to the director general has taken place; see $i d$. at 156 .

101 Thus, pursuant to an ordinance of Nov. 28, 1958, all major management officials of public corporations and public enterprises are now appointed by the Council of Ministers. In accordance with another ordinance of Nov. I7, 1958, former government members are now eligible for the posts of director general and chairman of the administrative council after a lapse of only six months (previously five years). See Lescuyer, supra note 182 , at II86.

${ }_{102}$ The law of Oct. I9, r946, specifically excludes the staff of these corporations from the realm of public law; see Drago, The Public Corporation in France, in W. Friedmann (Ed.), The Public CorpoRATION II3, I30 (1954).

${ }^{108}$ Decree of June 22,$1946 ;$ ibid.

${ }^{104}$ Compare Lasserre, supra note 189 , at 35 ; Rivero, supra note 167 , at 401 .

${ }^{105}$ On this problem of the dépassement du salariat compare Lasserre, supra note 189 , at $36,40-42$; Rivero, supra note 167 , at $409-410$. Relations were particularly strained during strikes in nationalized industries in 1948 and 1955 . 
has tended to produce conflicts on the management level. ${ }^{106}$ It should be remembered, however, that these corporations have to make regular business investments while maintaining comparatively high salaries for employees and low tariffs for consumers or users. ${ }^{197}$ Nationalized corporations have frequently been able to balance their budgets only by relying on state subsidies, public loans, or investment capital furnished by private or mixed corporations. ${ }^{188}$

\section{B. National Companies}

\section{x. Development}

Like industrial public corporations, national societiés or companies can be traced back to the end of the first World War; but the major types of such companies originated in the nationalizations following the collapse of the Vichy regime. Some of the national societiés have the character of joint stock companies in which the state has become the sole stockholder through nationalization and expropriation. In other companies, frequently called "mixed economic" enterprises, ${ }^{190}$ the state has acquired the majority of shares. The principal "one man corporations," i.e., companies in which the state is the sole stockholder, are the Banque de France and four large credit institutes, ${ }^{200}$ the Banque d'Algérie, ${ }^{201}$ a large number of insurance companies, ${ }^{202}$ and several other credit banks or funds. ${ }^{203}$ The "mixed" enterprises include the National Company of the Rhône, ${ }^{204}$ the National Railway Society (S.N.C.F.), ${ }^{205}$ the National Societies for Aeronautic Constructions, ${ }^{200}$ the National

${ }^{100}$ See Drago, The Public Corporation in France, in W. Friedmann (Ed.), The Public Corporution I13, I33 (1954).

${ }^{107}$ Compare Mainguy, La vente au coût marginal dans les secteurs de base d'une économie nationale, in BorteuX ET AL. 246 ff.

${ }^{108}$ Sec, e.g., J. M. Jeanneney \& C. A. Colliard, Economie et Droit de l'Electricite (i950).

${ }^{109}$ Compare J. E. Gopchot, Les SociḱtÉs d'Économie Mixte et L'AmÉnAGement du Teruitoire (1958), review Drago, R.D.P.1960.4I8.

${ }^{200} \mathrm{Law}$ of Dec. 2, 1945. The four institutes are Crédit Lyonnais, Société générale, Comptoir national d'escompte, and B.N.C.I.; see WALINE 635 (\$ I070).

${ }^{201}$ Law of May 17, 1946.

${ }^{202}$ Law of April 25, 1946. Compare Bouquet, Direction et contróle des Sociétés Nationales d'Assurances, in BorTeux ET AL. 169; Besson, Nationalisation et organisation de l'industrie des assurances, Dr. Soc. $2 x_{2}$ (1947).

${ }^{203} \mathrm{On}$ the nationalization of credit institutes compare Cabrillac, L'organisation du credit et les nationalisations de banques, J.C.P.1946.I.496; Hamel, La nationalisation du crédit, D.1946.Chron.VI.21; La nationalisation des grandes banques de dépót, DR. Soc. I (1950). The nationalization of credit institutions was not a uniform process. In the case of the four great credit institutes the transfer of assets to the state was accompanied by a transfer of management, while in the case of other credit banks, "nationalization" consisted simply of the creation of a national Credic Council for the purpose of general supervision of credit policy without any direct interference in the existing management and without transfer of bank capital to the state. See generally, WALINE 635 (\$ IO70).

204 Law of May 27, 1921.

${ }^{206}$ Decree of August 3I, I937. The establishment of the S.N.C.F. resulted from the transformation of debts-incurred by private railway companies in the form of state subsidies-into active participation by the state in the administration of railways on the basis of a contract between the state and the grantees of former railway concessions, effecting a transfer of a majority of stocks to the state; see $\mathrm{DE}$ Laubadère 229-23I. Compare also Mermier, La S.N.C.F., entreprise monopolistique, in BorteuX ET AL. 75; G. Fleury, Les Contrôles Exercés sur la S.N.C.F. Française (1958).

${ }^{306} \mathrm{Lav}$ of August II, 1937. 
Company Air France, ${ }^{207}$ the General Transatlantic Company, ${ }^{208}$ and, of a more recent date, the Real Estate Company of French Somalilarid, ${ }^{209}$ the Credit Institute of Senegal, ${ }^{210}$ and the Real Estate and Tourist Company of Overseas Departments. ${ }^{211}$

\section{Legal Regime}

The outstanding common feature of these national companies is that in their operation and business conduct they retain the character of commercial companies and are therefore governed primarily by commercial or private law. Even in cases where the establishment of a national société resulted from nationalization, the change in the ownership of shares has left the legal and economic identity of the company practically unaffected. The basic aim of these companies is to achieve profits and to conduct business successfully. With the exception of certain top management officials charged with the direction of the enterprise, the personnel of national companies obviously does not possess the status of civil servants. ${ }^{212}$ The relations between the companies and employees, users, suppliers, or third persons are entirely ruled by commercial law and thus within the jurisdiction of the general courts. ${ }^{213}$ All national companies are also subject to regular taxation.

National companies are even more comprehensively subject to private law than are industrial public corporations. There can be little doubt that the companies have title both to funds which existed prior to nationalization or the transfer of shares, and to funds which are acquired subsequently. This is true even where

${ }^{207}$ Law of June I6, 1948. Compare Lemoine, Air France devant la concurrence, in Borteux ET AL. Ir3.

${ }^{208}$ Law of Feb. 8, 1948.

${ }^{200}$ Decree of August 8, 1956.

310 Decree of August 17, 1956.

${ }^{211}$ Decree of Dec. 22, 1956. On the basis of a law of April 30, 1946, the French Minister of Overseas T'erritories has established a large number of other sociétés d'État; see ConNors, op. cit. supra note 25 , at 195 n.10, $196 \mathrm{ff}$.

${ }^{312}$ Compare, e.g., Fusilier, Le statut du personnel des entreprises nationalisées comparé au statut des agents de la fonction publique, R.D.P.1956.50T; Levasseur, $L a$ situation du personnel dans les entreprises nationalisées, in BoITeUX ET AL. 337,340; Etaix, La place du personnel dans la S.N.C.F., id. at 373; Hamel, Le nouveat statut professionnel des banques françaises, DR. Soc. 3I0, 349 (I946).

${ }_{213}$ Concerning S.N.C.F. see, C.E., Jan. 2I, I959, Vincent, R.D.P.I959.78r (while administrative courts have jurisdiction for annulment of tariffs established by S.N.C.F., they lack jurisdiction over the application of tariffs to individual users); C.C., Soc., March 25, I954, S.N.C.F. v. Précigout, Drorr Ouvrier 467 (1954); C.E., Oct. 26, I95I, Ortolan, D.r952.Somm.7; C.C., Soc., Nov. 26, I948, Veuve Thomas v. Soc. des chemins de fer économiques, Dr. Soc. 188 (r949), note Hébraud. Concerning Banque de France, compare C.E., Feb. 12, 1960, d'Eudiville, R.D.P.1960.838 (if administrative courts have jurisdiction over the violation of laws and regulations-governing the Bank or-disputes concerning its internal management, this competence must be viewed as an exception and interpreted in a restrictive manner); Oct. 31, r958, Devaux-Moutenot, R.D.P.I959.336 (since litigation involving the Bank belongs normally before the civil courts, Council of State has no jurisdiction over action against augmentation of discount rates); also Feb. I2, 1960, Kampmann, R.D.P.r960.857 (since governor of the Bank of France and other bank officials do not act as representatives of the Bank when participating in administrative decisions regarding credit control, action for liability of governor for alleged mistakes committed in credit control cannot be directed against the Bank); C.C., Soc, July I2, I950, Ardouin, D.I950.J.665, note Blaevoet, Dr. Soc. 38, x08 (195I) (Crédit Lyonnais). Cf. Levasseur, supra note 2r2; at $365 \mathrm{ff}$. Administrative courts usually have jurisdiction over administrative activities, or where contracts executed by company contain clauses exorbitantes :du^droit commsm; C.E., 'April 24, I959, S.N.C.F., R.D.P.r959.x054. 
the state is the sole shareholder, although the state obviously remains entitled to all assets resulting, from an eventual liquidation. ${ }^{214}$ By the same token, it would seem that the funds and properties of national companies are not exempt from attachment and execution. ${ }^{215}$ On the other hand, the right of these companies to make compositions with debtors or to resort to arbitration has lately been denied or at least restricted. ${ }^{216}$

While in their normal operation and business relations, national companies function like regular commercial enterprises, their relation to the state and to other supervising authorities presents a different picture. In this respect, the national companies resemble, to a degree, industrial public corporations in the sense that they partake of the dichotomy between private operation and public control. ${ }^{217}$ The major forms of public control have already been indicated in the discussion of industrial public corporations. Thus, the principal national companies-especially enterprises created pursuant to nationalization-are subject to various a posteriori controls in the form of supervision by parliamentary subcommitees, state inspectors, and state commissions, and financial examination by the Audit Commission and the Budget Court. ${ }^{218}$ In addition, activities or decisions frequently require prior consent of competent ministers or prior consultation with various public commissions. It must be pointed out, however, that the exercise of controls varies considerably among the different national enterprises. Thus, national banks and insurance companies normally enjoy a greater degree of independence than other companies. Furthermore, supervision is usually more rigid in the case of companies which receive state subsidies.

\section{Organization and Management}

The organization of national companies largely follows the pattern of other public or semi-public corporations, although their peculiar commercial character accounts for some structural variations. The major organs are a board frequently called "administrative council," and an executive organ usually consisting of a single director general. Due to their legal character as commercial corporations, national companies regularly have a further deliberative organ in the form of shareholders' "assemblies."219 Both the composition of these general assemblies and that of the administrative councils originally reflected the principle of tripartite and even quadripartite management, i.e., the equal distribution of seats among representatives

${ }^{214}$ See Vedel, Le régime des biens des entreprises nationalisées, in BorTeuX ET AL. 194.

${ }^{216}$ The draft law of 1948 based its distinction between two categories of "public enterprises" primarily upon the submission to or exemption from execution. Various lower tribunals have permitted execution against nationalized enterprises; Aix, Nov. 30, 1949, J.C.P.1950.2.5245 bis; contra: Paris, Dec. 22, 1948, S.r949.2.89, note Drago, J.C.P.1949.2.4729, note Lavau. Compare De Laubanire 239.

216 C.E., Dec. 13, 1957, Soc. nationale Vente des surplus, DR. Soc. 89 (1958), concl. Gazier. In regard to the recovery of debts, it is not entirely clear whether the right of "national enterprises" to issue self-executory orders-granted by decree of Nov. 5, 1953-belongs to all national companies. Cf. 2 VEDEL, DR. ADM. 478.

${ }^{217}$ Compare note 179 supra.

218 See, e.g., Bouquet, supra note 202, at $18 \mathrm{I} f$.

$21{ }^{\circ}$ Compare id. at $578 \mathrm{f}$. 
of the state; of employees; of consumers or users of the service; and in some cases, of technical experts. ${ }^{20}$ In order to avoid an impasse where the state was the only shareholder, representation in the assemblies and administrative councils was allotted to delegates of all the ministries related to the particular enterprise, as well as to delegates of employees and of various associations arbitrarily designated as users of the service. ${ }^{221}$ This device, however, could hardly conceal the fact that all the different delegates actually represent and depend upon a single shareholder-the state.

In all national companies, a gradual increase of the impact of state representation and state control resulted from the dwindling of tripartism or quadripartism. This trend was noticeable at first in one of the national companies, ${ }^{222}$ and later spread to other enterprises including public industrial corporations. The influence of the state is strengthened by the power of the government to appoint or participate in the appointment of the executive organ, usually the director general. ${ }^{223}$ Furthermore, the government is normally entitled to designate or at least to participate in the selection of the president of the administrative council. The relation between director general and the council president varies in the different companies. ${ }^{24}$ In the National Railway Company and in Air France, a factual division of competence seems to prevail in the sense that the president handles the external relations while the director general is in charge of internal operations. More frequently, however, the director general clearly predominates in all policy matters. ${ }^{225}$

On the whole, there is little disagreement regarding the technical efficiency and competence displayed in the management of national companies. ${ }^{226}$ Their internal organization still presents many unsolved problems, especially as regards relations between staff and management, ${ }^{227}$ the role to be played by employees and workers, and the representation of the users of the services. There are considerable differences among the companies in respect to financial and economic results. National banks and insurance companies present perhaps the most favorable economic picture. This is at least in part explained by the fact that these institutions have frequently

${ }^{290}$ The quadripartite formula of representation, i.e., the inclusion of technical experts, was applied particularly to the administrative organs of banks and insurance companies; see DE LAUBADikE 238; Bouquet, supra note 202, at I76.

$2 a 2$ Compare Waline 642 (\$ ro77).

229 Already in' 1948, the representation of "users" disappeared in the administrative council of Air France and was replaced by a vague category of "individuals outside the civil service"; at the same time, a fourth category of administrators, representing private capital, was created. See Rivero, L'évolution, in BorTEUX IT AL. $6_{3}$.

${ }^{222}$ Only in joint stock companies, i.e., primarily banks and insurance companies, the administrative council itself selects the director general with the approval of the government; see 2 VEDEL, DR. ADM. 475.

294 On paper, the legal pre-eminence of the president is recognized in the S.N.C.F. and in the navigation companies; see Chenot, supra note 183 , at 156.

ass Ibid.

920 See Rivero, Conclusion, in BorteuX ET AL. at $40 \mathrm{O}$.

${ }^{227}$ As in the case of public corporations, the staff of national companies are frequently entitled to form "staff committees"; compare C.E., May 2, 1959, Syndicat général du personnel d'Air-France, DR. Soc. 533 (I959), cond. Chardeau, L'institution des comités d'entreprise dans les sociétés nationales. 
been able to retain their original managing and executive personne ${ }^{228}$ and have continued to be subject to vigorous economic competition. ${ }^{228}$ Other companies have not always been equally successful and profitable. Some have needed continued or occasional help by state subsidies and private or public loans in order to balance their budgets. ${ }^{230}$ By and large, however, most national enterprises have done sufficiently well to refute the pessimistic prophecies of their original detractors and opponents.

\section{III}

\section{Public Law Influences on Other Corporations or Institutions}

The confluence and convergence of public and private law elements is not restricted to semi-public bodies and corporations. In the case of national companies, the influence of public control and rules of public administration on private enterprises is particularly strong, and this justifies their classification as "semi-public" bodies. But there are many other private institutions or companies which exhibitthough perhaps to a lesser degree-the infiltration of public law and the influence of public interest. The present context permits only a brief glance at the major examples of this infiltration and interaction.

In France, public law penetration into the strictly private sphere manifests itself primarily in two forms: first, in the performance of a "public service"231 by private organisms or individuals, and secondly, in the performance of a private service which is vaguely affected with a "general interest" or a consideration of "public utility." The classic example of the first category is the so-called concession, i.e., the quasi-contractual delegation of the exercise of a public function by administrative authorities to a private company or individual. ${ }^{232}$ The activities of the grantec, and especially his relations to users of the service and third persons, remain governed by private law and subject to the jurisdiction of ordinary courts, ${ }^{233}$ unless these activities involve the execution of public works. ${ }^{234}$ The public law influence, on the other

${ }^{228}$ This has been the case with insurance companies and national banks with the exception of the four old credit institutes; WALINE 635 ( $\$$ IO70); Bouquet, supra note 202, at 175-177.

${ }^{229}$ Compare Drago, The Public Corporation in France, in W. Friedmann (Ed.), The Public ConpoRATION II3, I32 (1954).

${ }_{280}$ For state subsidies given to some of these companies during 1953, compare id. at 135 .

${ }^{23 x}$ As previously mentioned, the implications of this concept are not very clearly defined today in French administrative law; however, the term continues to be used in this context both by legal writers and in court decisions.

${ }^{289}$ Concessions have had a considerable part in' the development of the modern French economy, especially in the installation of railways, streetcars, and the distribution of water, gas and electricity. On concession, compare Waline 534-535 ( $\$$ 903-906); 2 VEDEL, DR. AdM. 570 ff.; De Laubadère 217 ff.

${ }^{283}$ Concerning litigation between grantees and users or third persons, compare C.E., Jan، 2x, 1925, Chemins de fer algériens, Rec.p.136. Contracts between grantee and user are private law agreements; however, where user brings action against granting authority on account of negligence or fault in supervision of grantee, the litigation comes within the jurisdiction of administrative courts; C.E., Nov. 7, 1958, Société "Electricité et Eaux de Madagascar" et Territoire de Madagascar v. Nicola, R.D.P.1959:354. The grantee and his employees obviously are not civil servants or public agents.

${ }^{284}$ C.E., April 25, -I958, Veuve Barbaza, R.D.P.1958.ro09, I959.622, J.C.P.1958.2.10810, note Blaevoet, La compétence générale des juridictions administratives pour connaitre des dommages causés aux tiers par un ouvrage public. 
hand, is demonstrated primarily in the control function of the granting authority, ${ }^{235}$ its power to impose sanctions, ${ }^{236}$ and in its legal relations with the grantee. ${ }^{237}$ More recently, there is a tendency to admit the possibility of the performance of public services by private companies or individuals outside and irrespective of a concession contract. ${ }^{238}$ Thus, activities which are subject to administrative authorization - such as occupation of the public domain ${ }^{239}$ - have been declared to be public services and thereby assimilated to the exercise of a concession. ${ }^{240}$

The traditional example of the second category in French law is the already mentioned établissement d'utilité publique. ${ }^{241}$ In contradistinction to établissements publics, établissements d'utilité publique are not public bodies, nor do they perform

${ }^{385}$ C.E., Nov. 2I, 1958, Syndicat national des transports aériens, R.D.P.1959.348 (principle of freedom of commerce and industry cannot be invoked where exercise of profession depends on concession and administrative authorization). Administrative control can exceed the limits of the concession instrument, although control caninot amount to an actual take-over of the service by the granting authority; C.E., July I8, I930, Compagnie P.-L.-M., Rec.p.763. The granting authority is also entitled to modify unilaterally the concession instrument in order to adapt the service to changing public needs, C.E., March II, I9Io, Compagnie générale des tramways, S.IgIx.3.I, concl. Blum, note Hauriou; Jan. Io, 1902, Gaz de Deville-les-Rouens, S.1902.3.17, concl. Romieu, note Hauriou; while the grantee cannot unilaterally alter the dispositions of the instrument, C.E., March 5 , x943, Compagnie générale des Eaux, D.Crit.1944.J.12I. Compare also, A. Demichel, Le Contrôle de L'État sur les Organisms Privés (I960).

${ }^{280}$ These sanctions, which are available even in the face of contractual clauses to the contrary, may consist in the recovery of damages, in the take-over and execution of the service by the administration, and in the renunciation of the concession contract; compare C.E., Oct. II, I929, Compagnie SudAtlantique, Rec.p.892; March 30, 1928, Ville de Louhans, Rec.p.482.

${ }^{237}$ C.E., Dec. I6, 192x, Sassey, Rec.p.ro62.

${ }^{338}$ On this aspect, compare Waline $624-625$ ( $\$$ I957); I VEDEL, DR. ADM. 54-55; DE LAUBADÈrE 226. But see C.E., Nov. 13, x959, Navizet, R.D.P.1960.1034, concl. Heumann, at I040: "We on our part think that, in case of doubt, there is no legal or economic interest or advantage in expanding this category of hybrid organisms: private institutions performing a public service. This mixture of public and private law leads almost always to confusion and sometimes to administrative and financial disorder."

${ }^{380}$ C.E., Feb. 6, I948, Soc. Radio-Atlantique, R.D.P.I948.244, concl. Chenot; Feb. 6, I948, Compagnie carcassonnaise des transports en commun, R.D.P.1948.52, concl. Chenot; May 5, 1944, Compagnie maritime afr. or., R.D.P.x944.24, concl. Chenot.

${ }^{360}$ Apart from occupation of the public domain, courts have frequently recognized the execution of public services by private enterprises; see C.E., Dec. 9, 1959, Couturier, R.D.P.I960.350 (social security funds); June 2, I959, Syndicat industriel d'utilisation et transformation des fruits, pâtes de fruits et fruits secs, R.D.P.I959.780; T.C., July 2I, 1949, Hauptmann, Rec.p.6I3; C.E., June 28, 1946, Morand, Rec.p.r 83; Aug. 4, I944, Compagnie Alès, Froges et Camargue, Rec.p.225; Aug. 4, 1944, Compagnie des produits chimiques, S.1945.3.4; Feb. 27, 1942, Mollet, S.I942.3.41 (public service performed by Cité universitaire, a private foundation); May I3, I938, Caisse primaire Aide et Protection, Rec.p.4I7, D.1939.3.65, concl. Latournerie, note Pépy (primary social security funds); Dec. 20, 1935, Société des établissements 'Vezia, Rec.p.212, R.D.P.I936.I I8, concl. Latournerie. See also C.E., Jan. I3, I96x, Sieur Magnier, R.D.P.I96r.I55, concl. Fournier (the jurisdiction of administrative courts in litigation arising from the activity of private law institutions participating in the performance of a public service depends on the nature of the particular activity, i.e., on whether the activity is an expression of public authority or merely part of the normal operation of the institution).

${ }^{341}$ See Waline 355-358 ( $\$ \$$ 597-602); 2 Vedel, Dr. AdM. 462-464; De Laubadère 21 II-212. Such bodies may have the form of associations, mutual societies, or foundations, and may even be created by congregations; see C.E., July 9, r953, Foyers familiaux de la jeune fille, Rec.p.340, concl. Letourneur; of. also July $\mathrm{r}_{5}$, x959, Fédération française de tir, Libert, R.D.P.1960.317, note Waline. Significant examples of établissements d'utilité publique are the French Veterans' Union (ordinanice of May. 14, 1945); the former Organization for National Aid (law-decree of Oct. 9, 1939), replaced-later by the "Mutual Aid for the Liberation" organization (ordinance of Feb. 8, 1944); the National Savings Movement (ordinance of Oct. 13, r945); and various local savings banks, see C.C., Civ., March 5, 1856 , Caisse d'Epargne de Caen, S.I856.I.5I7, D.I856.I.I2I. 
a public service. ${ }^{242}$ Rather, these établissements are private corporations or other private institutions, and the services performed by them are of a private character. Consequently, their general operations are entirely subject to private law and to the jurisdiction of the ordinary courts. ${ }^{243}$ Nevertheless, relying on a rather vague notion of "public utility," 244 the government occasionally intervenes in the operation of these institutions through the selection of management officials, through financial inspections, ${ }^{245}$ or-though rarely-through the grant of certain administrative prerogatives. ${ }^{246}$ In recent decades this type of legal regime has been extended to other private institutions or companies which are sometimes called "private enterprises of a general interest" (entreprises privées d'intérêt général) ${ }^{247}$ and which, though entirely private in character and not charged with the exercise of a public service, are sometimes granted special administrative prerogatives, such as the right of eminent domain or the execution of public works. ${ }^{248}$

${ }^{213}$ Several criteria have been developed for the distinction between établissements publics and établissements d'utilité publique. At any early period, courts frequently relied on the origin of the institution, i.e., whether the creation resulted from an act of government or from private initiative; C.E., May 22, 1903, Caisse des écoles du VIe arrondissement de Paris, S.1905.3.33, note Hauriou, D.r904-3.I; June 2I, I9I2, Pichot, S.1913.3.43, concl. Blum, D.rgr5.3.9. However, it is now recognized that établissements publics may have originated in private initiative (e.g., the former French Law School of Cairo, C.E., Dec. 24, I937, de la Bigne de Villeneuve, D.H.1938.I85) while établissements d'utilité publique may be created by governmental action. The criterion of statutory designation' cannot be utilized in the case of institutions which originated prior to 1860 , when the distinction between the two forms of establishments was recognized; C.E., June 20, I9I9, Brincat, D.1922.3.15, note Puget, S.I924.3.43; Dec. 21, I906, Caisse diocésaine de Secours, Rec.p.947. After I860, the Legislature rarely has made use of direct statutory designation. The criterion of "public service" used in some decisions-C.E., July I, I938, Comité national de la maison de la France d'outre-mer, D.H.1938.552; July 2, 1938, Viel, Rec.p.615-is hardly reliable since public services may be performed by private organizations. Of equally doubtful value is the criterion of administrative control-C.C., Civ., March 5, 1941, Durand, D.A.r94r.J.I62-since établissements d'utilité publique are also subject to administrative supervision. Most writers today would agree that in the absence of legislative texts to the contrary, the extent of administrative prerogatives attributed to an institution is an important and comparatively reliable criterion; C.E., Dec. 20, I935, Société des établissements Vezia, R.D.P.1936.r3I-132, concl. Latournerie, even though établissements d'utilité publique may on occasion enjoy certain administrative prerogatives, see note 246 infra.

248 Compare T.C., Jan. 13, 1958, Demoiselle Berry, Rec.p.789 (jurisdiction of the civil courts over relations between institution and its personnel); also C.E., Jan. 12, 1951, Bompart, Rec.p.15 (institutions regularly caninot execute public works); June 4, I958, Boisson, Rec.p.303 (institutions cannot issue selfexecutory orders).

2*4 The attribution of this character is sometimes directly contained in the statute which creates the institution (compare ordinance of Oct. I3, I945, establishing the National Savings Movement); in other cases, the title is conferred upon existing bodies by governmental decree.

${ }_{245} \mathrm{Law}$-decree of March 20, 1939. Administrative control over foundations d'utilité publique has been relaxed by a decree of May 20, I955 (No. 55.615); see Waline 355 n.2 ( $\$ 598$ ).

${ }^{20}$ Thus, various insurance companies in Algeria qualified as établissements d'utilité publique are entitled to levy fiscal contributions; id. at $358(5602)$.

${ }_{247}$ Compare id. at $643-46$ ( $\$$ I078-84); De Laubadère 37-38, 225; B. Tricor, Essat sur les

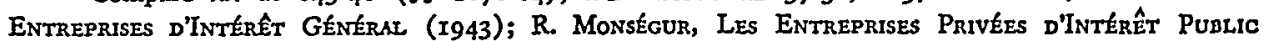
ET LES SocIÉtÉs D'Économie MIXTE (1942). Examples of such enterprises are thermal resources, various colonial insurance companies, and enterprises for the exploitation of mines and water falls (laws of April 2r, 1810, and Sept. 9 and Oct. 16, I9I9). The great majority of the latter enterprises have in the meantime been nationalized.

${ }^{248}$ C.E., Dec. 20, 1935, Société des établissements Vezia, R.D.P.1936.118, concl. Latournerie; $\mathrm{DE}$ LAUBADÈRE 38 . 


\section{Conctusion}

The proliferation of public and semi-public institutions has introduced considerable uncertainties and difficulties in the French administrative system. There are, at first, theoretical ambiguities connected with the problem of legal classification. Many of the more recent corporations are governed partly by public and partly by private law; and it is not yet certain whether this situation will engender a new juridical category, or whether the traditional dualism will prove stronger, thereby pulling the new organisms back into either the public or the private domain. However, these ambiguities should perhaps not be overemphasized. Legal categories. are supposed to follow rather than dictate the development of institutions.

Of a more serious nature are the difficulties connected with the actual operation of semi-public corporations and especially of the nationalized industries. Here, the preceding pages have pointed out many problems still awaiting solution, problems concerning financial and economic management, the status of workers and employees, and the participation of workers and users in the management process. Of major importance is the issue of the ultimate place of semi-public or nationalized enterprises in society, and the question whether existing controls of the state should be curtailed or further extended. ${ }^{249}$ Despite these persisting problems and uncertainties, the new organisms and institutions here discussed have demonstrated: by their operations the viability and efficacy of public participation in traditionally private endeavors. As was remarked by one astute observer, Professor Rivero: ${ }^{250}$

It has been proved today that the capitalist motor-or more exactly what is considered as such-namely, the search for individual profit, is not indispensable for the operation of a large-scale enterprise. Without stockholders greedy for dividends, without managers. avid for their share of profits, the nationalized enterprises have been able to develop theirproductivity, expand their fields of operations, and reduce their production costs.

\footnotetext{
${ }^{240}$ Vedel advocates the greatest possible assimilation of public enterprises to private commercial: activities; see esp. Vedel, Le régime des biens des entreprises nationalisées, in BoITEux ET AI. IgI ff. On. the other hand, Chenot favors a strengthening of state supervision and especially of the democratic control of Parliament as a means to counteract the danger of an irresponsible technocracy; Chenot, Direction et contrôle des entreprises nationalisées, $i d$. at $160-63$. For a conciliatory view attributing the determination of objectives to governmental organs and the execution of these objectives to the nationall enterprises, see Rivero, Conclusion, id. at 408.

${ }^{250} I d$. at $40 \mathrm{r}$.
} 